

\title{
Hypotheses voor afname van de visstand in het IJsselmeer
}




\section{Hypotheses voor afname van de visstand in het IJsselmeer}


Keywords: visstand, ecologie, ecosysteem, IJsselmeer, Markermeer

Opdrachtgever: Rijkswaterstaat Midden Nederland

T.a.v.: Ria Kamps-Mulder

Zuiderwagenplein 2

8224 AD Lelystad

Dit rapport is gratis te downloaden van https://doi.org/10.18174/523624

Wageningen Marine Research verstrekt geen gedrukte exemplaren van rapporten.

Wageningen Marine Research is ISO 9001:2015 gecertificeerd.

(c) Wageningen Marine Research

Wageningen Marine Research, instituut binnen de rechtspersoon Stichting

Wageningen Research, hierbij

vertegenwoordigd door Drs.ir. M.T. van

Manen, directeur bedrijfsvoering

KvK nr. 09098104,

WMR BTW nr. NL 8113.83.696.B16.

Code BIC/SWIFT address: RABONL2U

IBAN code: NL 73 RABO 0373599285
Wageningen Marine Research aanvaardt geen aansprakelijkheid voor gevolgschade, noch voor schade welke voortvloeit uit toepassingen van de resultaten van werkzaamheden of andere gegevens verkregen van Wageningen Marine Research. Opdrachtgever vrijwaart Wageningen Marine Research van aanspraken van derden in verband met deze toepassing.

Alle rechten voorbehouden. Niets uit deze uitgave mag weergegeven en/of gepubliceerd worden, gefotokopieerd of op enige andere manier gebruikt worden zonder schriftelijke toestemming van de uitgever of auteur. 


\section{Inhoud}

Samenvatting

$1 \quad$ Inleiding

$2 \quad$ Kennisvraag

6

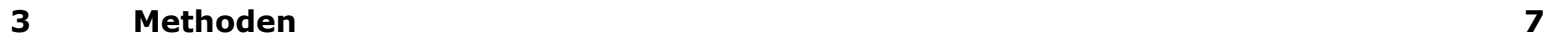

4 Resultaten $\quad 8$

4.1 Veranderingen in de visstand - monitoringsgegevens $\quad 8$

4.2 Ruimtelijke verdeling $\quad 11$

4.3 Huidige visstand: bemonstering met A-toomkuil $2019 \quad 12$

$\begin{array}{ll}4.4 & \text { Aanvullende observaties door experts } \\ \end{array}$

$5 \quad$ Mogelijke oorzaken huidige toestand IJsselmeer $\quad 14$

$\begin{array}{lll}5.1 & \text { Afname nutriënten en voedsel voor vis } & 14\end{array}$

5.2 Klimaatverandering $\quad 16$



$\begin{array}{lll}5.4 & \text { Visserij } & 18\end{array}$

$\begin{array}{ll}5.5 \text { Exoten } & 19\end{array}$

$\begin{array}{ll}5.6 & \text { Milieuvreemde stoffen } \\ 5.7 & 19\end{array}$

$\begin{array}{lll}5.7 & \text { Uitspoeling vis via spuisluizen Afsluitdijk } & 20\end{array}$

6 Conclusies, hypotheses en aanbevelingen $\quad 21$

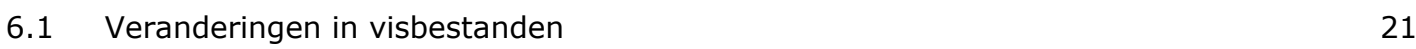

$\begin{array}{ll}6.2 \text { Vergelijking Markermeer en IJsselmeer } & 21\end{array}$

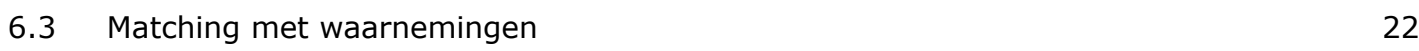

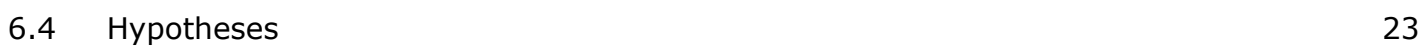

6.4.1 Hypothese 1: Voedselgebrek - gebrekkige natuurlijke nutriëntenstromen 24

6.4.2 Hypothese 2: Helder water - nieuwe baseline maar (nog) gebrek aan veiligheid

6.5 Aanbevelingen en toekomstperspectieven $\quad 25$

6.5.1 Wat kan verder onderzocht worden? 26

6.5.2 Welke maatregelen liggen voor de hand? 28

$\begin{array}{llr}7 & \text { Kwaliteitsborging } & 29\end{array}$

$\begin{array}{lr}\text { Literatuur } & \mathbf{3 0}\end{array}$

$\begin{array}{ll}\text { Verantwoording } & 32\end{array}$

$\begin{array}{lll}\text { Bijlage } 1 \quad \text { Zooplankton } & 33\end{array}$ 


\section{Samenvatting}

De afgelopen decennia is de visstand in het IJsselmeer veranderd. In recente jaren is vooral het gebrek aan grotere en oudere vis opvallend. In dit rapport worden de belangrijkste waarnemingen en hypotheses beschreven aan de hand van rapporten, ongepubliceerde gegevens, wetenschappelijke literatuur en visies van diverse experts betrokken bij ecosysteemontwikkelingen in het IJsselmeer. Bij de analyse en het opstellen van hypotheses is ook gebruik gemaakt van waargenomen overeenkomsten en verschillen in veranderingen in de visstand en het functioneren van het Markermeer

De belangrijkste mogelijke oorzaken om de waargenomen veranderingen in de visstand te verklaren zijn de veranderingen in nutriëntenbelasting en daarmee de voedselbasis voor jonge vis, visserij, en toegenomen helderheid van het water waardoor interacties tussen vogels en vis versterkt lijken te worden. Klimaatveranderingen (temperatuur en wind) spelen een rol voor de voedselsituatie. De rol van milieubelastende stoffen is onduidelijk: er lijken geen ongunstige trends te worden gevonden in stoffen die gemeten worden, maar gezien de veelheid van typen en soorten potentieel belastende stoffen zijn negatieve effecten hiervan niet uit te sluiten. Exoten (invasieve grondels, quaggamosselen en andere bodemfauna) grijpen in op het functioneren van het ecosysteem voor vis op verschillende manieren: als mogelijk voedsel of juist als concurrenten om voedsel met inheemse visfauna, of het versterken van de helderheid van het water (quaggamossels). Deze mogelijke effecten zijn tot dusver nauwelijks onderzocht.

Uit de analyse van waarnemingen en onderzoeksgegevens komen twee hypothesen sterk naar voren:

(1) door gebrekkige nutriëntenstromen die mogelijk samenhangen met (onbegrepen) bodemprocessen en het grotendeels ontbreken van natuurlijke oevers ontstaat voedselgebrek voor verschillende vissoorten en levensfasen

(2) het steeds vaker helder worden van het IJsselmeer en gebrek aan (natuurlijke) schuilmogelijkheden leidt ertoe dat veel jonge vis zich onveilig voelt voor roofvissen en visetende watervogels.

Het samenspel van nutriënten, waterkwaliteit en de voedselbasis voor vis is complex, zowel over seizoenen als ruimtelijke patronen over het meer, maar meetreeksen in het IJsselmeer zijn zeer beperkt. Het verdient aanbeveling om de monitoring van waterkwaliteit in het IJsselmeer op te delen in het noordelijk en zuidelijk IJsselmeer met meetpalen op meerdere relevante locaties. Daarnaast zijn regelmatiger metingen aan de voedselbasis van vis (zoöplankton en benthos) wenselijk om veranderingen in de visstand beter te begrijpen. Het samenspel tussen helderheid en het gedrag van vogels en vissen verdient eveneens nadere analyse.

Op basis van bovenstaande hypothesen zouden maatregelen om de omstandigheden voor vis te verbeteren in eerste instantie gericht moeten zijn op het ontwikkelen van grootschalige natuurlijke oevers met rijke oever- en onderwatervegetatie. Dergelijke oeverzones met rietmoerassen kunnen veiligheid bieden aan kleinere vis en zorgen voor een grote productie aan organisch materiaal dat ten goede komt aan voedselketens. 
De afgelopen jaren lijkt de opbouw, samenstelling en biomassa van de visstand in het IJsselmeer sterk af te wijken van de decennia daarvoor. Niet alleen zijn de visstanden in het algemeen afgenomen, maar ook zijn er verschuivingen in soortsamenstelling en leeftijdsopbouw zichtbaar in zowel de jaarlijks uitgevoerde vismonitoring als in observaties van vissers. Zo zien we in het IJsselmeer bijvoorbeeld veel nuljarige baars maar nauwelijks oudere (vooral in 2018 en 2019) en zijn door vissers veel jonge blankvoorns in havens geobserveerd. De indruk bestaat dat de visstand in het IJsselmeer uit vooral jonge vis bestaat en dat deze niet doorgroeit tot een ouder bestand.

Voor deze trends en waarnemingen zijn uiteenlopende verklaringen te bedenken over hoe het ecosysteem van het IJsselmeer op dit moment functioneert, bijvoorbeeld verschuivingen in voedselwebstructuur, gebrek aan voedsel voor jonge vis om door te groeien, veranderingen in ruimtelijke verspreiding omdat het water helderder wordt, veranderd jaaggedrag van visetende watervogels, effecten van visserij, klimaatverandering, etc.

De vraag daarbij is of dit langetermijn of tijdelijke veranderingen zijn en of er maatregelen denkbaar zijn die het systeem wellicht in een meer stabiele toestand zou kunnen brengen. Leidend daarbij is de Europese opgave die Rijkswaterstaat en de provincies hebben om vanuit de Kaderrichtlijn Water en Natura2000 te voldoen aan de daarbij behorende doelen. Tevens streeft Rijkswaterstaat naar een robuust en ecologische gezond ecosysteem en in afstemming met het ministerie van Landbouw, Natuur en Voedselkwaliteit naar een economisch rendabele en duurzame beroepsvisserij met een vangstcapaciteit die passend is bij de ontwikkelingen in draagkracht van het IJsselmeergebied.

In discussies over de huidige toestand van het IJsselmeer worden uiteenlopende hypotheses genoemd die de oorzaak zouden kunnen zijn van de verslechtering van (schub)visbestanden in het IJsselmeer en Markermeer. In dit document beschrijven we kort een aantal veranderingen in de visstand over de jaren in het IJsselmeer en Markermeer wat betreft de aantallen, verschuivingen in soortsamenstelling, leeftijdsopbouw en in de verspreiding van vissen over het meer. Vervolgens worden een aantal (recente) aanvullende waarnemingen en observaties gepresenteerd. Deze waarnemingen komen met name uit een gesprek dat plaatsvond d.d. 21 nov 2019 in Bilthoven met diverse visexperts.

Vervolgens bespreken we de meest waarschijnlijke hypotheses die observaties en tijdreeksen van de visstand mogelijk kunnen verklaren. Daarbij wordt zowel naar de ontwikkelingen in het IJsselmeer als in het Markermeer gekeken omdat de overeenkomsten en verschillen tussen de meren ons mogelijk iets kunnen leren over de oorzaken van de huidige toestand in het IJsselmeer. Tenslotte worden enkele suggesties gedaan voor nadere uitdieping van hypotheses en mogelijke richtingen voor beheersmaatregelen gegeven. 


\section{Kennisvraag}

De afgelopen decennia is de visstand in het IJsselmeer sterk veranderd. In recente jaren is vooral het gebrek aan grotere en oudere schubvis opvallend. Hiervoor zijn verschillende verklaringen denkbaar. Vanuit de beheersopgaven is er behoefte aan meer duidelijkheid over in hoeverre het ecosysteem van het IJsselmeer duurzaam is en welke ontwikkelingen of maatregelen passen bij de draagkracht van het systeem. Om daar een beter inzicht in te krijgen is heeft Rijkswaterstaat gevraagd een QuickScan uit te voeren voor het IJsselmeer op basis van bestaande kennis, gegevens en waarnemingen.

Deze QuickScan heeft tot doel:

1. een logische samenhang tussen de bestaande kennis, gegevens en waarnemingen te beschrijven;

2. mogelijke (nieuwe) verklaringen en hypotheses te formuleren waarbij, daar waar nuttig, een vergelijking tussen het Markermeer en IJsselmeer wordt gemaakt;

3. hypotheses en maatregelen waarvan een positief effect verwacht mag worden op de visstand en die passen binnen de doelstellingen van de Kaderrichtlijn Water en Natura2000 uit te werken;

4. onderzoeksvoorstellen te doen die de hypotheses en denkbare maatregelen verder kunnen onderbouwen. 


\section{$3 \quad$ Methoden}

In dit rapport worden de belangrijkste waarnemingen en hypotheses over recente veranderingen in de schubvisstand in het IJsselmeer uitgewerkt.

Basisinput voor de hypothesevorming is de discussie tussen experts over de huidige toestand van visbestanden in het IJsselmeer (Bilthoven, 21 november 2019), aangevuld met literatuuronderzoek (wetenschappelijke publicaties, rapportages met betrekking tot IJsselmeergebied) en gegevens over bemonsteringen en visbestandsontwikkelingen in IJsselmeer en Markermeer (tijdreeksen Wageningen Marine Research, bemonstering met A-toomkuil in 2019 door ATKB).

Op basis hiervan zijn mogelijke verklaringen geanalyseerd die de recente ontwikkelingen in de visstand zouden kunnen verklaren. Vervolgens zijn hieruit twee hypotheses geformuleerd. Dit zijn niet noodzakelijkerwijs elkaar uitsluitende hypotheses, maar hypotheses die meerdere belangrijk aspecten (waarnemingen, ecologisch functionering) beschrijven. Bij de analyse en het opstellen van hypotheses is ook gebruik gemaakt van kennis en gegevens over het Markermeer.

Deze hypotheses zijn voorgelegd en bediscussieerd met diverse experts werkzaam op het gebied van en/of betrokken bij ecosysteemontwikkelingen in het IJsselmeer. Op basis van deze expertconsultaties zijn de hypotheses verder aangescherpt.

Op basis van de resultaten van de expertconsultatie zijn onderzoeksvragen geformuleerd om de hypotheses waar wenselijk verder te kunnen onderbouwen, en mogelijke beheersmaatregelen in het kader van beleidsdoelstellingen voor de opgaven van de Kaderrichtlijn water, Natura 2000 en duurzame visserij besproken. 


\section{$4 \quad$ Resultaten}

\subsection{Veranderingen in de visstand - monitoringsgegevens}

Hieronder wordt een kort overzicht gegeven van een aantal veranderingen in de hoeveelheid vis, de leeftijdsopbouw, de soortsamenstelling, en verspreiding in het IJsselmeer, om de situatie van nu te beschouwen in een historisch perspectief. De gepresenteerde gegevens zijn gebaseerd op de jaarlijkse monitoring met grote kuil of (vanaf 2012) boomkor (data Wageningen Marine Research). Deze gegevens zijn bruikbaar om veranderingen over de jaren in beeld te brengen. De soortsamenstelling en leeftijdsopbouw zijn niet representatief omdat sommige soorten beter worden gevangen dan andere en kleinere vis doorgaans beter wordt gevangen dan grotere vis in deze monitoring.

Veranderingen in het aalbestand worden niet meegenomen in de analyses omdat de recruitment wordt bepaald door de aalstand over heel Europa. Wel kan opgemerkt worden dat er recentelijk relatief meer vrouwelijke alen worden waargenomen, welke groter kunnen groeien dan mannelijke aal en bij oudere leeftijd schieraal worden.

In Figuur 1 zijn van de meest voorkomende soorten het gewicht per hectare uitgezet (CPUE, Tien et al., 2020). Eind jaren negentig werden er jaarlijks nog behoorlijke aantallen spiering gevangen, terwijl daarna steeds vaker jaren met weinig spiering worden waargenomen. Brasem is sterk afgenomen, met name vanaf 2006. Pos is in de jaren 1990 toegenomen tot een belangrijke soort in het IJsselmeer, maar sterk afgenomen vanaf 2015. Dit valt min of meer samen met de opkomst van de invasieve soorten zwartbekgrondel en Pontische stroomgrondel en met een grotere biomassa baars. In het Markermeer is de visstand sterk afgenomen rond 2000, met name voor spiering, brasem en pos. In 2017 werd een tijdelijke opleving van de visstand genoteerd, waarbij de opleving van vooral het snoekbaarsbestand leidde tot een belangrijke verschuiving van de nettenvisserij naar het Markermeer (Tien et al. 2020).

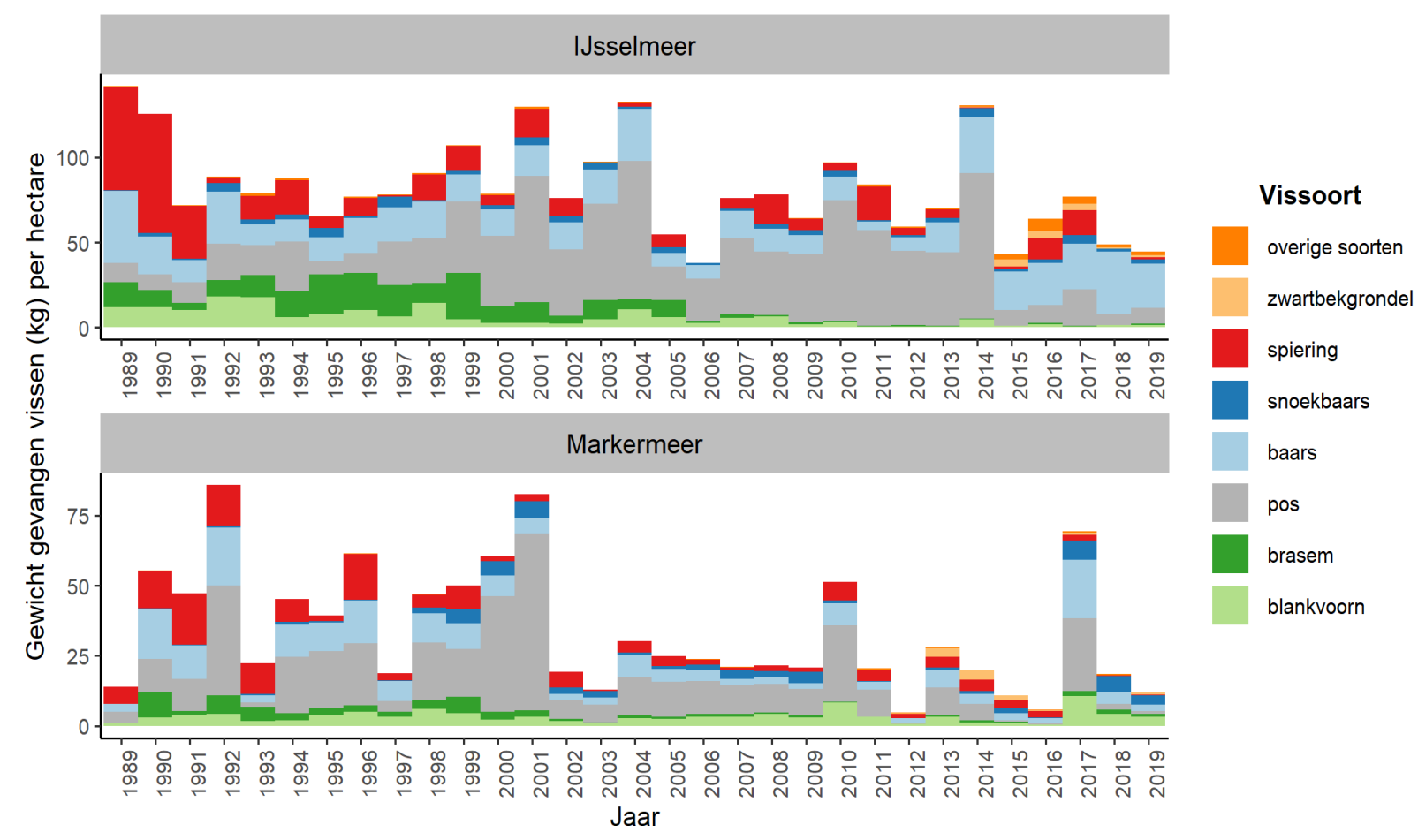

Figuur 1 Index voor biomassa vis op basis van bemonstering met grote kuil/boomkor (kg per hectare bevist oppervlak) tussen 1989 en 2019 van de meest voorkomende vissoorten van IJsselmeer en Markermeer. 
Wanneer we verschillende leeftijdsgroepen nader beschouwen zien we dat vooral vissen van 2 jaar en ouder enorm achteruit zijn gegaan in het IJsselmeer, met name brasem (vanaf 2006) en blankvoorn (vanaf 2011) (Figuur 2). De biomassa eenjarige vissen zijn ook geregeld laag in deze periode, vooral brasem, blankvoorn en pos vanaf 2011/2012. Voor pos valt een toename op rond 2000 (nul- en eenjarige vis) gevolgd door afnamen vooral bij nuljarige vanaf 2015. Daarentegen zijn de hoeveelheden nuljarige baars vanaf 2014 juist hoog in het IJsselmeer, terwijl in de meeste jaren eenjarige en oudere baars juist schaarser zijn geworden.

De samenstelling en leeftijdsopbouw in het Markermeer ziet er opvallend anders uit (Figuur 3). Hoeveelheden gevangen vis in $\mathrm{kg}$ per hectare zijn over het algemeen lager dan in het IJsselmeer. Maar waar de leeftijdsopbouw van het IJsselmeer verschuift naar jonge vis, wordt in het Markermeer nog wel relatief veel oudere vis waargenomen, zonder duidelijke neergaande trend zoals in het IJsselmeer, behalve een sterke terugval van brasem sinds 2002. Opvallend is ook de relatief grote aantallen oudere vis sinds 2017 in het Markermeer, met name blankvoorn, maar ook baars, brasem en snoekbaars worden meer gevangen dan in voorgaande jaren. Tegelijkertijd ontstaan sterke jaarklassen $(0+)$ in 2017 voor snoekbaars en baars die de jaren daarna ook terug te zien zijn in de oudere jaarklassen en voor goede vangsten van snoekbaars in de commerciële visserij zorgen (Tien et al. 2020).

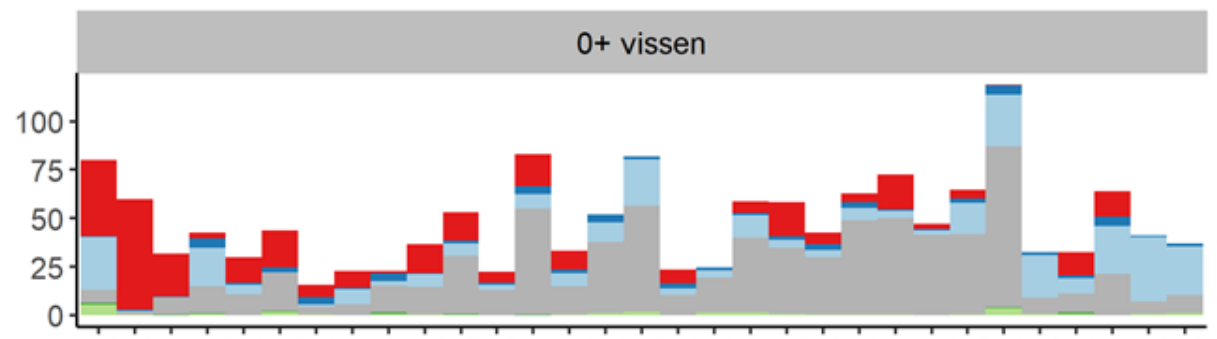

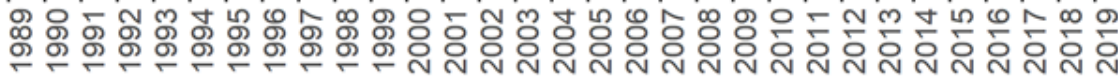

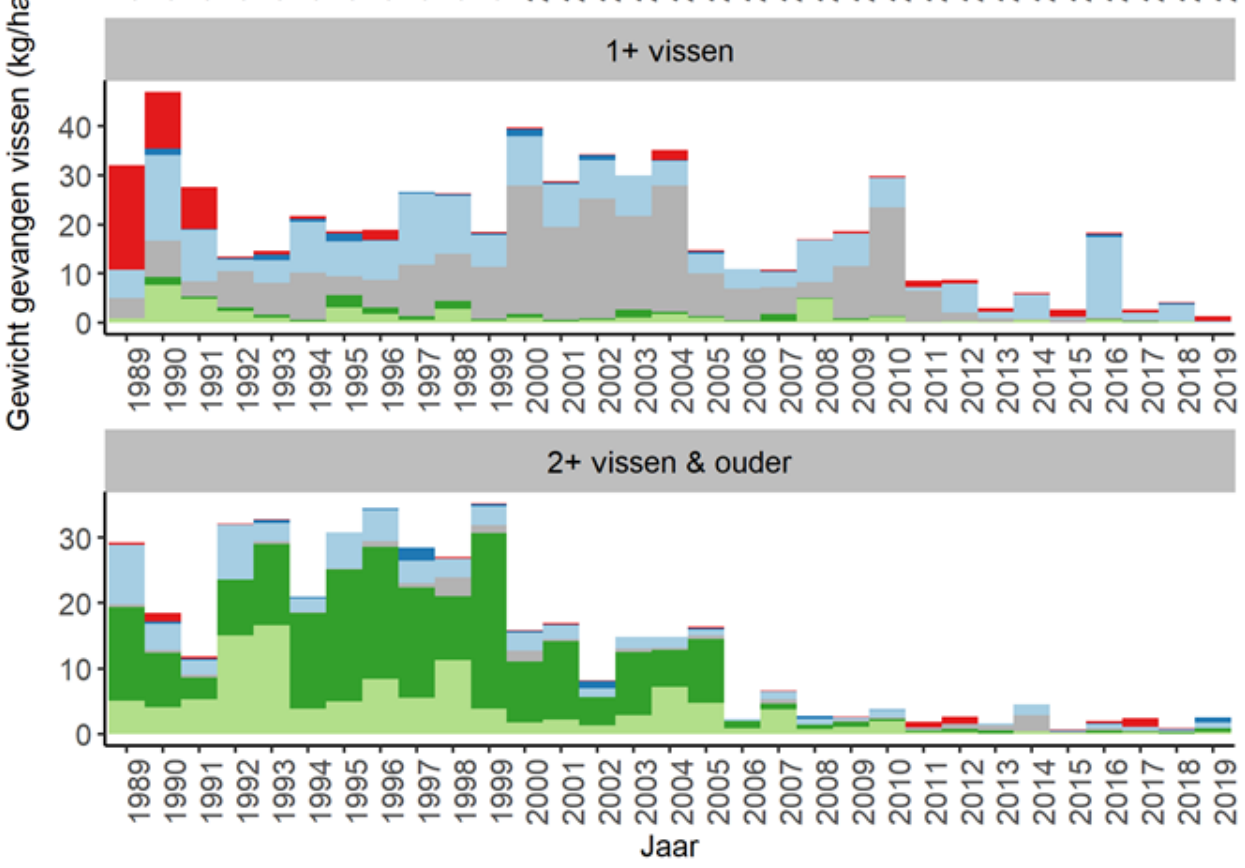

Figuur 2. Biomassa vis in kg per hectare bevist oppervlak tussen 1989 en 2019 van de meest voorkomende vissoorten van het IJsselmeer. Vissen zijn geselecteerd op leeftijdsklasse op basis van jaarlijkse lengteverdelingen. 

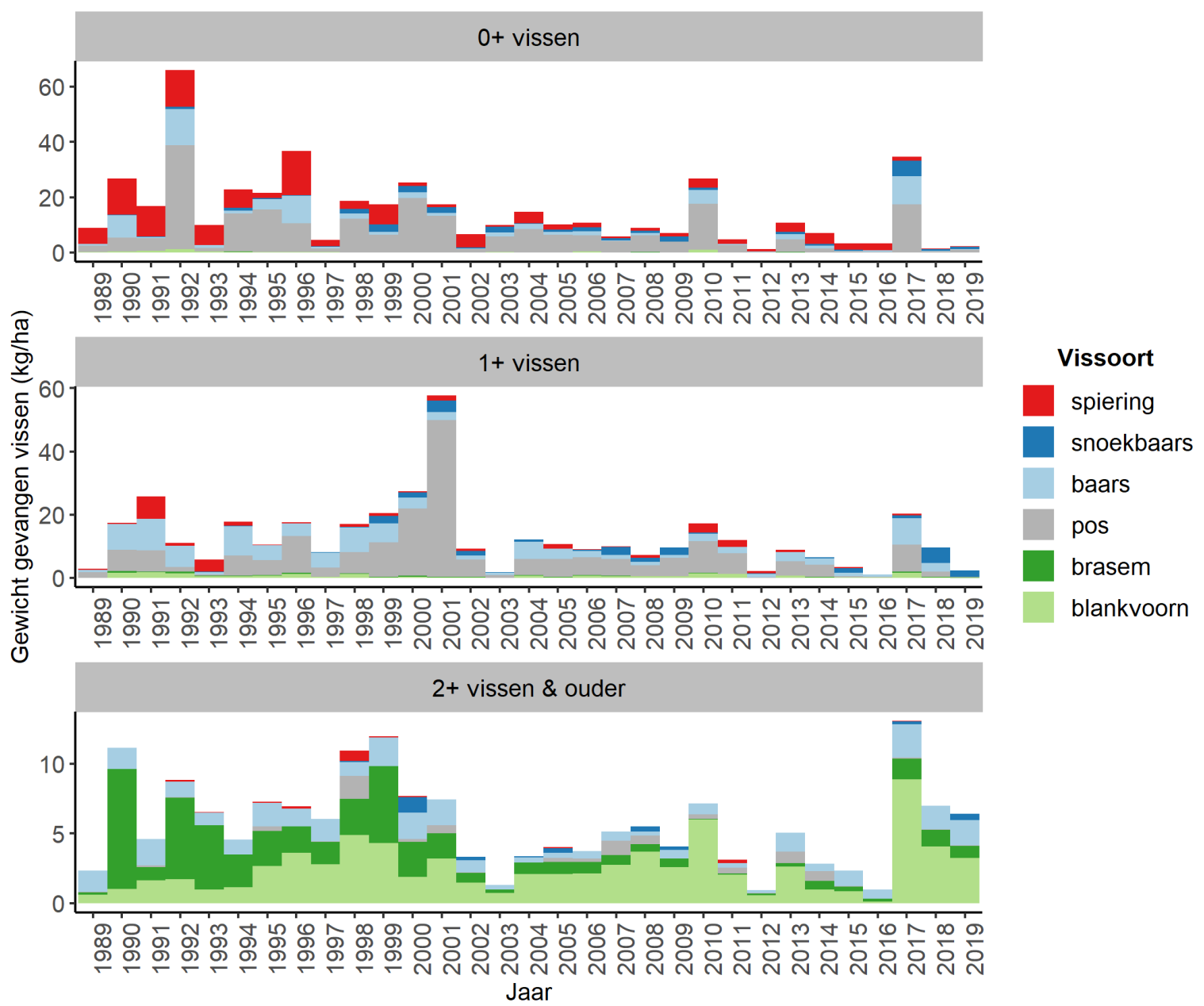

Figuur 3 Biomassa vis in kg per hectare bevist oppervlak tussen 1989 en 2019 van de meest voorkomende vissoorten van het Markermeer. Vissen zijn geselecteerd op leeftijdsklasse op basis van jaarlijkse lengteverdelingen.

Een voetnoot bij al deze figuren is dat er vrij grove leeftijdsschattingen zijn gebruikt op basis van lengteverdelingen per jaar. Groei en dus lengte kunnen tussen jaren behoorlijk verschillen waardoor niet in alle jaren het onderscheid tussen nuljarige, eenjarige en oudere vis goed te maken is. Echter, een meer grondige analyse van vier commercieel beviste schubvissoorten die recent heeft plaatsgevonden laat een zelfde beeld zien. Tien et al. (2020) tonen dat het aandeel grote/oude baars, blankvoorn, brasem en snoekbaars vanaf 1992 afneemt tot in het laatste decennium. Hier lijkt ook dat oudere vis eerder of sterker zijn afgenomen dan jonge vis. 


\subsection{Ruimtelijke verdeling}

Veranderingen in het ecosysteem kunnen ook van invloed zijn op de ruimtelijke verdeling van vis. In Figuur 4 zijn per vijfjaars-periode de veranderingen in respectievelijk het noordelijk IJsselmeer, zuidelijk IJsselmeer en Markermeer uitgezet. Hierbij is gekozen voor alleen de kleinere vis $(<18 \mathrm{~cm})$ omdat daar de beste gegevens van zijn en dit tevens het prooibestand uitmaakt voor visetende vogels en roofvissen (grotere baars en snoekbaars). Met name vanaf de periode 2000-2005 lijkt de verspreiding van spiering, pos en baars zich meer te concentreren tot locaties in het noordelijk deel van het IJsselmeer (ten noorden van de lijn Enkhuizen-Lemmer), terwijl het zuidelijk IJsselmeer in betekenis afneemt voor deze soorten (met uitzondering van baars in recente jaren).


1990-1994 1995-1999 2000-2004 2005-2009 2010-2014 2015-2019

Figuur 4 Veranderingen visbestand baars, blankvoorn, pos, snoekbaars, spiering en zwartbekgrondel van $18 \mathrm{~cm}$ en kleiner in respectievelijk het noordelijk IJsselmeer, zuidelijk IJsselmeer en Markermeer per periode van 5 jaar. N.B. Verhoudingen tussen soorten zijn niet representatief. 


\subsection{Huidige visstand: bemonstering met A-toomkuil 2019}

In 2019 is een uitgebreide visstandsbemonstering uitgevoerd door ATKB, beroepsvissers en WMR in het IJsselmeer en Markermeer (Vrooman et al. 2020). Daarbij zijn met een grote A-toomkuil ( $5 \mathrm{~m}$ hoog, $12 \mathrm{~m}$ breed) en stortkuil ( $1.5 \mathrm{~m}$ hoog, $10 \mathrm{~m}$ breed) de openwaterhabitats bemonsterd. De omvang van de netten is zodanig dat een breed spectrum van soorten en grootteklassen wordt bemonsterd, hetgeen een aanvullend beeld geeft van de huidige visstand, omdat de jaarlijkse bemonstering met grote kuil/boomkor relatief minder grotere vis vangt (Vrooman et al. 2020). In figuur 5 zijn voor IJsselmeer en Markermeer de belangrijkste resultaten gepresenteerd. In het IJsselmeer en Markermeer werden in 2019 gemiddeld dezelfde dichtheden vissen gevangen (totale CPUE bijna gelijk), maar werden in het IJsselmeer beduidend minder meerjarige vissen gevangen dan in het Markermeer; met name grote snoekbaars en blankvoorn werden meer waargenomen in het Markermeer, terwijl pos en spiering meer in het IJsselmeer werden waargenomen.

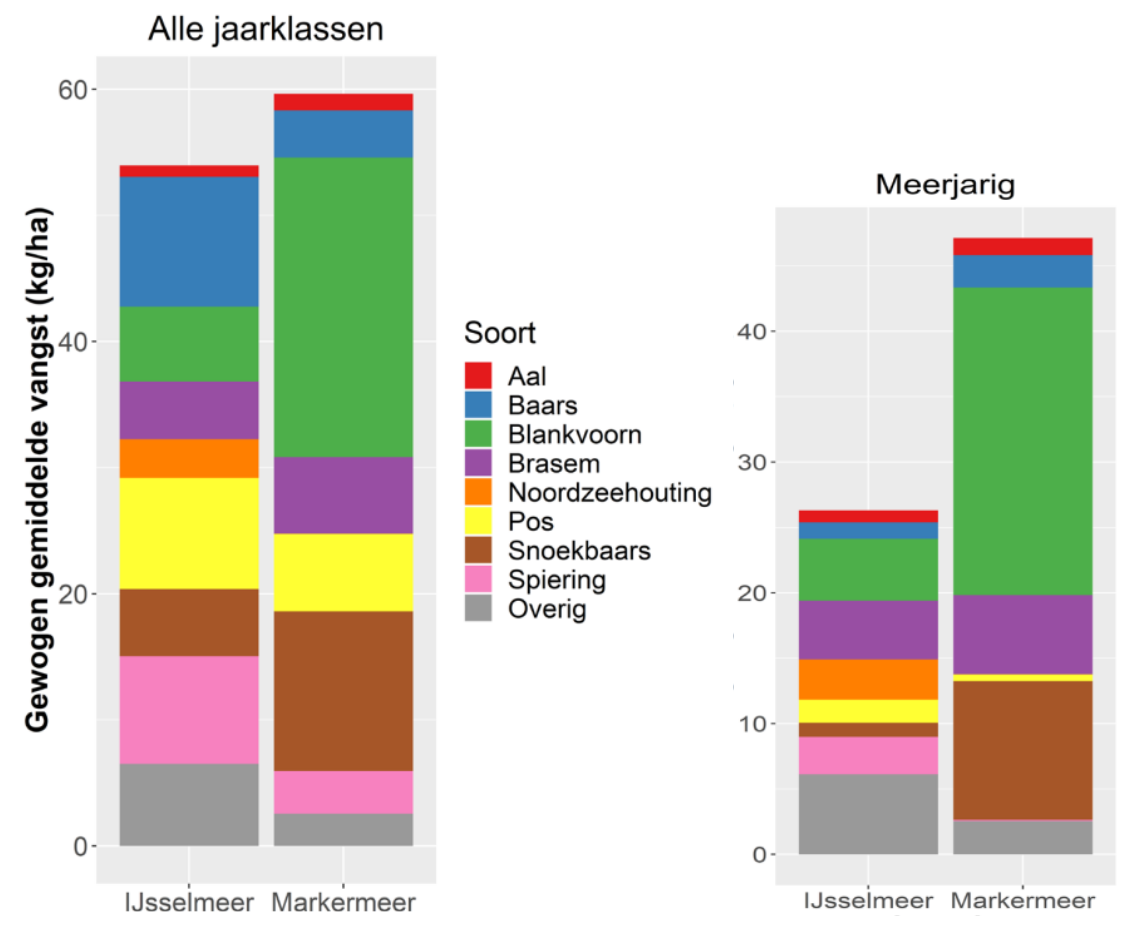

Figuur 5. Index voor visstand (CPUE in $\mathrm{kg}$ per hectare bevist oppervlak, gewogen gemiddelde over diepteklassen) per meer, voor alle jaarklassen (links) en meerjarige vis (rechts) op basis van de vangsten van de A-toomkuil en de stortkuil in 2019 (uit: Vrooman et al. 2020). 


\subsection{Aanvullende observaties door experts}

Op initiatief van Rijkswaterstaat (RWS) is 21 november 2019 een expertbijeenkomst gehouden bij Sportvisserij Nederland (Bilthoven), waaraan deelnamen: Jaap Quak (SVN), Jan van der Winden (LEN), Jouke Kampen (ATKB), Gerard Manshanden, Joep de Leeuw (WMR), Ruurd Noordhuis (Deltares), Harm van de Geest (UvA), Marjoke Muller, Mascha Lichtendahl, Ria Kamps-Mulder, Albert Remmelzwaal en Roel Doef (RWS). Daarbij werden mogelijke veranderingen in de visstand in het IJsselmeer en denkbare verklaringen besproken. In onderstaande zijn de belangrijkste observaties puntsgewijs samengevat.

\section{Insecten}

- $\quad$ Er zijn veel minder muggen in het IJsselmeergebied in vergelijking met de jaren 1980 en 1990. Wellicht is dit een indicatie voor een verandering in de voedselbasis?

Vogels

- Het menu van visdieven verandert. In 2017 werden vooral nuljarige baars en spiering en matige aantallen snoekbaars aan de jongen gevoerd, in 2018 vooral spiering en in 2019 hoofdzakelijk baars.

Vis algemeen

- $\quad$ Er wordt veel jonge vis gezien terwijl de middenklasse en grote individuen ontbreken

- $\quad$ Vis bevindt zich vooral in het noordelijk IJsselmeer

- $\quad$ Er is weinig vis in het vroege voorjaar; de piek in vis is pas laat in het seizoen

- $\quad$ In 2018 is veel vis van de rivieren naar het IJsselmeer getrokken

Aal

- $\quad$ Aal is gemiddeld groter en langer geworden (mogelijk vanwege een toename van het aantal vrouwtjes die pas later vet en schier worden?)

- $\quad$ Rode aal is gemiddeld magerder geworden in het IJsselmeer. Door voedselgebrek of doordat er meer vrouwtjes zijn gekomen (vrouwtjes blijven langer dun en worden pas bij grotere lengte vet en schier)?

- De aalstand is ingestort en de relatieve verbetering t.o.v. vorige jaren is nog steeds heel weinig vergeleken met hoe het vroeger was.

\section{Baars en snoekbaars}

- Jonge snoekbaars is klein en mager in het IJsselmeer, maar in veel betere conditie in het Markermeer

- Baars en snoekbaars blijven klein in IJsselmeer maar niet in Markermeer. Is er mogelijk een gebrek aan overschakel voedsel? Baars en snoekbaars leven van zoöplankton als ze klein zijn maar moeten als ze groter worden overschakelen op het eten van vis. Kreeftachtigen zoals aasgarnalen of spiering als kleine slanke vis kunnen belangrijk zijn voor overschakelen van plankton- naar visdieet.

- $\quad$ Er zijn weinig grote individuen

\section{Blankvoorn}

- Grote aantallen jonge blankvoorn in havens IJsselmeer (Medemblik), maar nauwelijks grotere

- Heel veel blankvoorn, ook grotere, in het Markermeer (belangrijkste soort in biomassa in Atoomkuilsurvey 2019)

Houting

- Veel houting in het IJsselmeer, zowel groot als klein, en neemt toe (?)

- Vooral aanwezig in ondiepten

- Verspreid steeds meer, ook in het Markermeer

Zwartbekgrondel

- Typische populatiecurve van kolonisatie van een exoot: aanvankelijk sterke toename (vanaf 2015), daarna sterke afname (door Witte stippenziekte in 2018), daarna stabilisatie?

- $\quad$ De rivierdonderpad is verdwenen in het IJsselmeergebied, mogelijk als gevolg van de zwartbekgrondel?

Spiering

- Spiering was verdwenen in warme zomer van 2018, in 2019 nieuwe generatie doet het relatief goed, maar geen grote aantallen 


\section{$5 \quad$ Mogelijke oorzaken huidige toestand IJsselmeer}

Er zijn verschillende oorzaken denkbaar die de hierboven besproken veranderingen en recente observaties kunnen verklaren. Hieronder worden de belangrijkste hiervan behandeld. Alhoewel de mogelijke oorzaken en ecologische mechanismes apart van elkaar worden besproken, is het zeer waarschijnlijk dat een combinatie van factoren de veranderingen veroorzaken. In hoofdstuk 6 wordt ingegaan op mogelijke combinaties van factoren.

We bespreken hier zowel zogenaamde bottom-up als top-down processen. Bottom-up processen gaan vooral over de draagkracht van een systeem; zijn er veranderingen te verwachten in hoeveel vissen het systeem kan herbergen gezien veranderingen in bijvoorbeeld voedselcondities of klimaat.

Daarnaast kunnen aantallen vis kan ook top-down gecontroleerd worden door bijvoorbeeld predatie en visserij.

\subsection{Afname nutriënten en voedsel voor vis}

De hoeveelheid vis die in het meer kan overleven kan sterk afhangen van de voedselproductie van het meer. De hoeveelheid nutriënten die beschikbaar zijn vormen een belangrijke input die bepalend kan zijn voor de omzettingen in het systeem en daarmee de voedselproductie. Relaties tussen hoeveelheid nutriënten zoals fosfaat $(P)$, stikstof $(N)$ en koolstof $(C)$ en productie van geschikt voedsel zijn echter vrijwel nooit direct. Die relaties hangen namelijk in belangrijke mate af van de structuur en het functioneren van het voedselweb, ofwel hoe trofische relaties worden gestuurd in het meer, bijvoorbeeld voornamelijk via plankton (pelagische deel van het voedselweb) of juist via bodemfauna (bentische deel van het voedselweb). Voor kleine soorten vis en voor alle jonge (maar van sommige soorten ook oudere) vis is zoöplankton de belangrijkste voedselbron (zogenoemde planktivoren). De samenstelling en productie van zoöplankton is afhankelijk van onder meer de fytoplanktonsamenstelling, welke op haar beurt weer door tal van abiotische en biotische factoren wordt bepaald. Zoöplankton is een verzameling van allerlei soorten en soortgroepen die sterk in grootte variëren en in de tijd van het jaar waarin ze zich ontwikkelen. Voor vislarven en de jonge levensstadia daarna zijn de schakeling van verschillende typen zoöplankton als voedselbron van levensbelang (Van Emmerik \& Quak 2020). Van het voorkomen en de jaarlijkse dynamiek van verschillende zoöplanktongroepen zijn bijzonder weinig gegevens beschikbaar en van de veranderingen over de tijd is al helemaal weinig bekend (zie echter bijlage 1). Toch zijn er interessante veranderingen de afgelopen decennia te noteren in nutriëntenstromen en algensamenstelling die reden kunnen zijn voor mogelijk toenemende voedselschaarste voor planktivore vis.

De nutriënten-aanvoer in het IJsselmeer over de afgelopen decennia is vrij recent beschreven (Noordhuis, 2010; Noordhuis et al. 2014). De toevoer van fosfor en stikstof (ammonium) van de Rijn is sinds begin jaren 80 afgenomen. Deze nutriënten zijn belangrijk, samen met zonlicht, voor de groei van fytoplankton zoals algen en sommige bacteriën. In het wetenschappelijk eindrapport van het ANTonderzoek (Noordhuis et al. 2014) werd geconcludeerd dat fosfaat in de jaren '90 sterk afnam en vervolgens ook stikstof. Aangenomen wordt dat na ca 2004 gehaltes P en N zodanig zijn gedaald dat de groei van fytoplankton beperkt wordt. Vergeleken met het Markermeer heeft het IJsselmeer altijd een iets hogere biomassa aan fytoplankton gehad door een hoger doorzicht waardoor licht voor fotosynthese tot op grotere diepte doordringt. Recent onderzoek in het Markermeer van UvA en NIOO laat overigens zien dat niet de hoeveelheid fytoplankton op zich maar dat licht in combinatie met nutriënten beperkend is. Belangrijker dan de hoeveelheid fytoplankton is dat de samenstelling, grootteverdeling en kwaliteit (P/C-ratio) van fytoplankton zijn veranderd. In het Markermeer spelen ook interacties tussen sediment en algen (vlokvorming) een rol (Brinkmann et al. 2019) die gestuurd worden door wind (stormfrequentie die samenhangt met klimaat). Het is onbekend in welke mate dat 
eventueel ook in het IJsselmeer optreedt. Al met al is de voedselsituatie dus uitermate complex, en spelen processen en interacties tussen waterkolom en de bovenste bodemlagen een rol. Op dit moment wordt al het nodige onderzoek gedaan, maar liggen nog veel vragen open voor zowel het Markermeer als het IJsselmeer (zie notities discussie Werkgroep Levend Markermeer, mei 2020).

Het is op basis hiervan dan ook moeilijk in te schatten hoe de situatie van zoöplankton (hoeveelheid, soort- en groottesamenstelling, seizoensdynamiek, ruimtelijke patronen) op dit moment is als voedsel voor vis in verschillende levensstadia in verschillende delen van het IJsselmeer en Markermeer. In 2019 zijn echter weer zoöplanktongegevens verzameld (Rijkswaterstaat/Aquasense, ongepubliceerd) in het IJsselmeer en Markermeer, die vergeleken kunnen worden met gegevens uit 1996 (Noordhuis 2000, zie bijlage 1). Daarin valt op dat in 1996 veel zoöplankton in het eerste gedeelte van het zomerhalfjaar werd waargenomen, met name ook rotiferen, in tegenstelling tot in 2019, toen de aantallen in de eerste helft van het voorjaar en de zomer laag waren, maar juist in de tweede helft van de zomer (augustus en september) hoog met opvallend veel Chydorus. De hoeveelheden zoöplankton kunnen sterk variëren van jaar tot jaar dus het is te vroeg om daar directe conclusies aan te verbinden, maar gezien de rol van rotiferen voor vislarven (Van Emmerik \& Quak 2020) en verschillen in voedselkwaliteit tussen bijvoorbeeld Chydorus (lage energieinhoud) en Daphnia en Bosmina (hoge energieinhoud; Vijverberg \& Frank 1976), kunnen deze waarnemingen, wanneer deze representatief zouden blijken te zijn voor de huidige situatie, ons op een interessant spoor zetten. In het verleden werd in het noordelijk IJsselmeer in elk geval groter zoöplankton aangetroffen dan in het zuidelijk IJsselmeer en Markermeer (Van Eerden et al., ongepubliceerde gegevens van 2012), wat mogelijk het gevolg is van grote concentraties filterende mossels, een sterke concurrent om fytoplankton voor zoöplankton, in het zuidelijk IJsselmeer. De hoeveelheid groter zoöplankton beïnvloedt direct de groei van bijvoorbeeld spiering (Mous et al. 2003).

Uit metingen van WMR aan de groei van jonge vis in hun eerste groeiseizoen zien we overigens dat de groei van jonge vis (met name bij baars) eerder toe dan af lijkt te nemen. Bij algemeen voedselgebrek zou je juist kleine, magere vis verwachten. Voedselgebrek zou echter ook al in het voorjaar op kunnen treden, bijvoorbeeld wanneer jonge visstadia nog afhankelijk zijn van rotiferen en kleine copepoden (Van Emmerik \& Quak 2020), hetgeen zou kunnen leiden tot voedselgebrek en vroege sterfte; het geringe aantal rotiferen in 2019 is daarom een interessant gegeven. De jonge vis die echter die fase overleeft zou later in de zomer mogelijk betere voedselsituaties kunnen treffen met minder concurrenten, waardoor ze harder groeien. Dit zou een verklaring kunnen zijn voor de relatief weinig jonge baars en spiering die we zien in het najaar, maar die in goede conditie verkeren in de loop van de zomer en het najaar.

Een ander idee dat heerst is dat doorgroei van het jonge roofvisbestand vooral beperkt wordt door een gebrek aan overgangsvoedsel zoals grotere watervlooien, aasgarnalen of spieringen voordat overgeschakeld kan worden naar een visdieet. Dit zou mogelijk een verklaring kunnen zijn voor een lage overleving van eenjarige baars en de magere nuljarige snoekbaars in het IJsselmeer. Voor baars is te zien dat er de afgelopen jaren veel nuljarige zijn in het IJsselmeer, maar dat deze cohorten met uitzondering van 2016 niet teruggevonden worden als eenjarige vissen en bijna lijken verdwenen als meerjarige vissen. Gegevens over eventueel beperkte beschikbaarheid van overgangsvoedsel ontbreken echter.

De afname vanaf 2006 van blankvoorns in het IJsselmeer zou gedeeltelijk kunnen komen door afname van voedsel. Blankvoorns eten onder meer driehoeksmosselen. Deze mosselen zijn in kwaliteit achteruit gegaan (minder vlees per schelp) en daarnaast heeft sinds $2009^{1}$ een andere invasieve soort, de quaggamossel, de plek van driehoeksmossels in slechts enkele jaren grotendeels ingenomen. Deze mossel is minder geschikt voor consumptie door vis (en duikeenden) doordat de schelp moeilijker te kraken is en nog minder vlees bevat dan driehoeksmossels. In het Markermeer zijn de mosselschelpen kleiner en zwakker dan in het IJsselmeer en wellicht nog wel eetbaar voor grotere blankvoorn. Dieetonderzoek van blankvoorns zou hier verder inzicht in kunnen geven.

\footnotetext{
${ }^{1}$ Voor het eerst in het IJsselmeer waargenomen in 2007 en vanaf 2009 zo ver uitgebreid dat effecten op de helderheid van het water zichtbaar waren (R. Noordhuis, pers comm)
} 
Ten slotte lijkt ook de bodemfauna sterk veranderd en vooral de biomassa wormachtigen sterk verminderd (P. Verdonschot, pers comm). Voor brasem zijn wormachtigen een belangrijke voedselbron. Wellicht heeft dit bijgedragen aan vermindering van het bestand grotere brasem. Systematische gegevens van het benthos ontbreken echter en ook het dieet van brasems in het IJsselmeer en Markermeer is hoegenaamd niet onderzocht.

\subsection{Klimaatverandering}

Klimaatverandering betekent in eerste instantie een gemiddeld hogere temperatuur. Dat geldt zowel voor de winterperiode (geen ijs bijvoorbeeld) als in de zomerperiode. Daarbij kunnen er ook meer extreme weersituaties voorkomen (hittegolven, stormen), al is de voorspelbaarheid daarvan beperkt. Voor koudbloedige dieren als vissen betekent een hogere temperatuur een hogere voedselbehoefte. In de winter is de voedselproductie echter laag: weinig zonlicht betekent weinig algen en geen waterplanten, waardoor ook de zoöplanktonproductie zeer laag is. Bij koude winters gaan vissen in winterrust, maar bij hoge watertemperatuur wordt wel energie verbruikt zonder dat dat gecompenseerd wordt door voedselproductie. In de zomermaanden kunnen hoge temperaturen zorgen voor lagere zuurstofspanning omdat de concentratie zuurstof afneemt met toename van de watertemperatuur. Voor soorten met een hoge zuurstofbehoefte kan een hoge temperatuur daarom leiden tot verhoogde sterfte (De Leeuw, 2007). Bij een hogere temperatuur neemt het metabolisme en dus de voedselbehoefte toe, maar wanneer de voedselproductie minder is geworden (zie 5.1) kan klimaatverandering het effect van voedselgebrek dus versterken. Dat geldt ook voor de winterperiode: in de winter is de voedselproductie laag, maar in zachte winters moeten vissen meer interen op hun reserves omdat hun metabolisme hoger is bij hogere temperaturen.

Klimaatverandering kan voor een koudwatersoort als spiering, die in Nederland inmiddels bijna de zuidgrens van zijn verspreidingsgebied bereikt, leiden tot een sterke inkrimping van areaal van voorkomen (Jeppesen et al., 2012). Dit kan mede een reden zijn dat de spieringstand lager is geworden - al of niet in combinatie met een mogelijk geringere zoöplanktonproductie (4.4.1) - en er niet of nauwelijks meer op spiering gevist wordt. In Frankrijk, Zuid-Engeland en Estland zijn spieringpopulaties ook sterk verminderd in samenhang met temperatuurveranderingen. Andere soorten zoals snoekbaars en brasem zijn eurytherme soorten die bij een bredere range in temperaturen kunnen functioneren. Deze soorten hebben dus mogelijk een voordeel ten opzichte van andere soorten met de toename in temperatuur (Jeppesen et al., 2012).

Effecten van temperatuurveranderingen zien we ook terug in veranderingen in groeisnelheid: voor veel soorten neemt de groeisnelheid toe (snoekbaars, baars, data WMR) maar dat kan ook leiden tot een slechtere conditie als er onvoldoende voedsel is. Wellicht verklaart dat waarom snoekbaars snel kan groeien als er voldoende prooivis is, maar sterk vermagert wanneer deze niet bereikbaar is en zoöplankton niet langer een optie is.

Bij hogere watertemperaturen kunnen soorten vroeger gaan paaien, maar het is mogelijk dat dat niet synchroon loopt met de ontwikkelingen in beschikbaar voedsel. Wanneer voedselbeschikbaarheid en voedselbehoefte uit de pas gaan lopen voor bepaalde soorten kan dat aanzienlijke consequenties hebben voor populatieontwikkelingen (Van Emmerik \& Quak 2020)

Klimaatverandering heeft ook invloed op de hoeveelheid en perioden in het jaar met regen, en daarmee op de afvoer van rivieren. Dat beïnvloedt zowel de hoeveelheid nutriënten (4.4.1) als de hoeveelheid sediment (4.4.2) en vermoedelijk ook de hoeveelheid vis die mogelijk vanaf de IJssel naar het IJsselmeer komt. Met name tussen 2005 en 2015 was de afvoer van de Rijn relatief laag (Noordhuis, 2019 concept). Extremen in de afvoer, dus perioden met uitzonderlijk hoge afvoer in bijvoorbeeld voorjaar, najaar en winter, of juist extreem lage waterstanden in de zomer, kunnen verplaatsingen van vis van de rivieren naar het IJsselmeer bevorderen. Dit kan bijvoorbeeld hebben bijgedragen aan de observatie dat veel jonge vis van de rivieren naar het IJsselmeer is getrokken in 2018 (J. Kampen, pers. comm.), toen de afvoer van de Rijn in de periode juli t/m oktober historisch laag was. 


\subsection{Helder water: risico voor predatie door vogels}

De laatste jaren is het gemiddelde doorzicht toegenomen, met name in het zuidelijk IJsselmeer. In het hele IJsselmeer en Markermeer komen steeds vaker perioden met een doorzicht van meer dan $2 \mathrm{~m}$ voor (Figuur 6). Helderheid wordt voor een belangrijk deel bepaald door een zeer hoge filtercapaciteit van quaggamossels, die er voor zorgen dat met name het zuidelijk IJsselmeer erg helder is (Noordhuis et al. 2014). De voedselkwaliteit van quaggamosselen (hoeveelheid vlees per schelp) is laag en de schelp relatief dik in vergelijking met driehoeksmossels, waardoor quaggamossels minder worden gepredeerd door vissen en vogels. De toename van doorzicht wordt ook deels verklaard door minder afvoer van zwevend stof van de rivieren, minder algen, en mogelijk door perioden waarin zwavelbacteriematten worden gevormd, hetgeen vermoedelijk weer samenhangt met een lagere frequentie van stormen (R. Noordhuis 2019). Algen zijn gemiddeld kleiner geworden welke echter weer kunnen zorgen voor een verminderd doorzicht omdat deze het licht meer verspreiden (scattering) dan grotere algen (Noordhuis, 2010).

Een verhoogd doorzicht heeft een sterk effect op het gedrag van vissen: bij een doorzicht groter dan ca $0.5 \mathrm{~m}$ Secchi trekt vis zich terug dichter bij de bodem (Mous, 2000; van Eerden \& Voslamber, 1995). Ook kan vis, bij langduriger perioden van helder water, zich terugtrekken in troebeler en diepere delen van het meer (Mous 2000; Mous et al. 2004), inclusief zandputten (De Leeuw \& van Donk 2020). Deze patronen zijn waargenomen voor spiering en snoekbaars, maar gelden waarschijnlijk in meer of mindere mate voor de meeste vissoorten, zeker de predatiegevoelige kleinere vis. Dit ontwijken van helder water is hoogstwaarschijnlijk om het risico van predatie door vogels en roofvissen te verminderen (Beekman \& Platteeuw 1994; Piersma et al. 1988, Piersma et al. 1998). Daarnaast is snoekbaars aangepast aan het jagen in troebel water door een lichtversterkend vlies in de ogen (tapetum lucidum). Grotere snoekbaars mijdt daarom lichtsterke omstandigheden zoals (ondiep) helder water.

Dat vluchtgedrag voor visetende vogels mogelijk een rol kan spelen wordt bevestigd doordat verschuivingen optreden in het ruimtelijk gebruik van vogels. Aalscholvers zijn geleidelijk aan meer in het IJsselmeer gaan broeden (Van Eerden et al. 2005). Sinds 2000 blijven aalscholvers ook overwinteren en duiden slaapplaatstellingen erop dat aalscholvers steeds meer van het noordelijk IJsselmeer gebruik maken (Witteveen+Bos 2008), daar waar nog de grotere concentraties prooivis voorkomen (Figuur 4). Ook de foerageergebieden van futen, zaagbekken en nonnetjes lijken zich geleidelijk meer van het Markermeer naar het (noordelijk) IJsselmeer te hebben verplaatst (Van Eerden et al. 2005). Een mogelijk groter aantal visetende vogels bij helderder water kan vluchtgedrag van kleinere en jongere vis versterken. Waarnemingen van grote concentraties jonge blankvoorn in havens lijkt dit beeld te bevestigen.

Het aantal diepe gebieden en natuurlijke schuilmogelijkheden voor vis in bodemstructuren zoals stenen, holen, takken, geulen en vegetatie zijn in het algemeen zeer beperkt in het IJsselmeer en Markermeer. In het westelijk Markermeer neemt het areaal waterplanten in de zomer toe, maar dit biedt alleen beschutting in de zomermaanden. Daarnaast is het Markermeer nog regelmatig vrij troebel en zijn er recent diepe zandwinputten gegraven/uitgebaggerd ten behoeve van aanleg van eilanden, vooroevers en oeverzones. Hiervan maken kleine vissen gebruik als schuilmogelijkheid voor piscivore vissen en vogels (De Leeuw \& Van Donk 2020). In het IJsselmeer is het oppervlak waterplanten zeer beperkt (Friese kust) en het water doorgaans aanzienlijk helderder dan in het Markermeer, met name in het zuidelijk IJsselmeer. In het noordelijk IJsselmeer komen diepere geulensystemen voor en is het doorzicht minder. Potentiële prooivis zou zich hier veiliger kunnen voelen en tezamen met dat de voedselvoorziening waarschijnlijk beter is (5.1) zou dit kunnen verklaren waarom vis zich meer in het noordelijk deel terug zou kunnen trekken. Het terugtrekken van vis op een kleiner oppervlak zou uiteindelijk weer zijn weerslag kunnen hebben op de lokale voedselbenuttingsmogelijkheden (lokale uitputting) en daarmee groeimogelijkheden.

Helderheid kent echter een sterke seizoensdynamiek en grote, moeilijk te voorspellen variatie over de tijd (Figuur 6). Om de effecten van helderheid en de reacties van vissen en vogels goed te begrijpen zou de variatie in helderheid en het gedrag van vissen en vogels in aanzienlijk meer detail bestudeerd moeten worden dan nu mogelijk is met de beschikbare gegevens. 


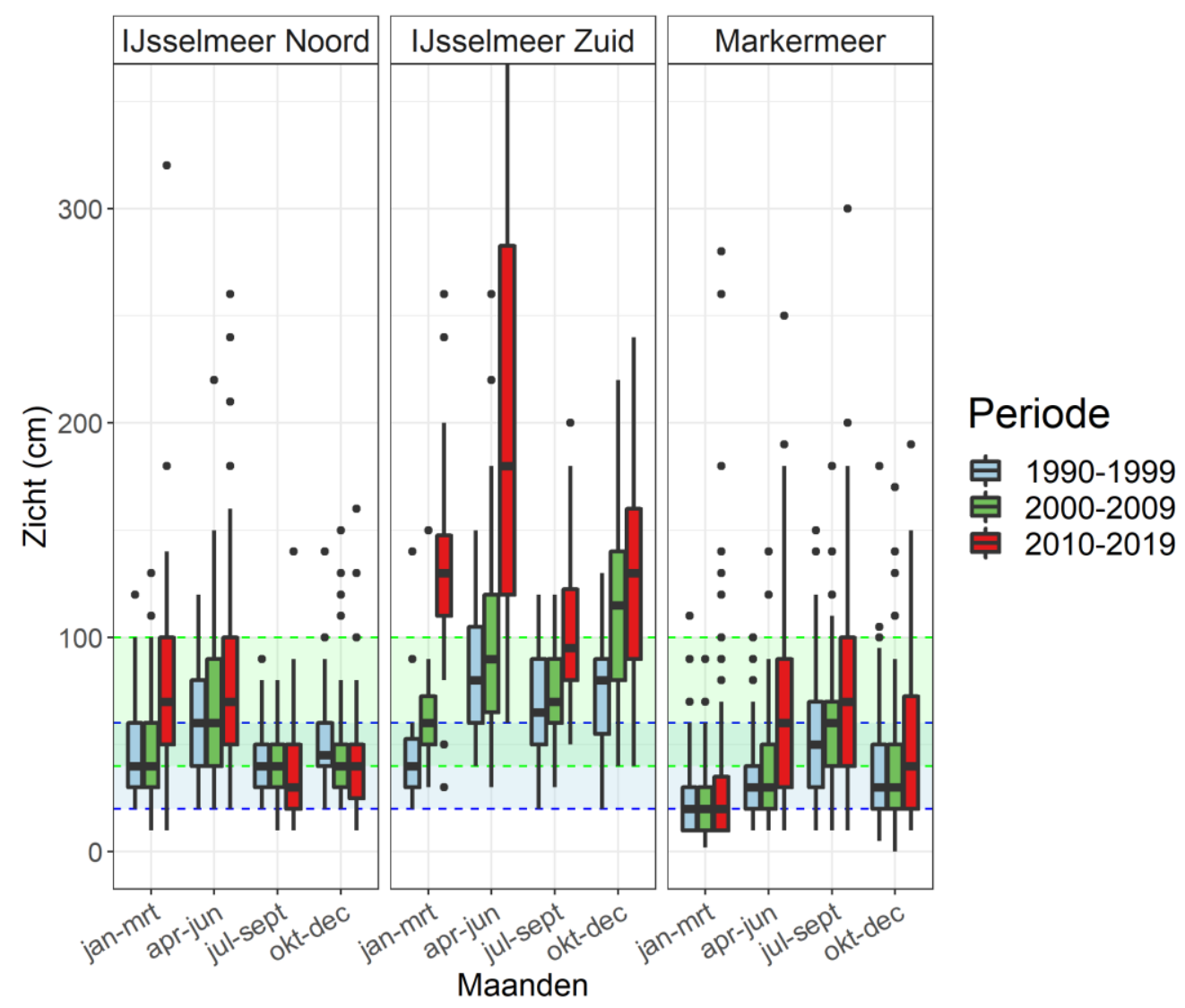

Figuur 6 Doorzicht (Secchi diepte) in centimeters in het noordelijk (Vrouwezand) en zuidelijk IJsselmeer (Houtrib) en Markermeer (diverse locaties) over de tijd. Doorzicht is weergegeven in periodes van drie maanden (x-as) en van 10 jaar (kleur). De gekleurde rechthoeken omsloten door onderbroken lijnen geven goede vangstomstandigheden aan voor nonnetje (blauw) en aalscholver (groen)(Van Eerden \& Voslamber 1995).

\section{$5.4 \quad$ Visserij}

De sterke afname van grote vis kan ook samenhangen met intensieve visserij. Zowel nettenvisserij op grotere schubvis (snoekbaars, baars, blankvoorn, brasem) als zegenvisserij op brasem lijkt intensief ten opzichte van wat het IJsselmeer en Markermeer produceren (De Leeuw et al. 2008; Tien et al. 2020) en zou bij kunnen dragen aan de sterke vermindering van met name de hoeveelheid oudere vis vanaf 2005 in het IJsselmeer. Zegenvisserij op brasem is omvangrijk maar wordt niet systematisch geregistreerd en wordt voor een zeer belangrijk deel ondergerapporteerd omdat vangsten niet in openbare bronnen worden gedocumenteerd en niet meegenomen kunnen worden in vangststatistieken.

Intensieve visserij kan zorgen voor ongebalanceerde leeftijdsopbouw onder visbestanden. Effecten daarvan zijn niet altijd direct zichtbaar omdat niet alle leeftijdsgroepen representatief bemonsterd worden, mede doordat bijvoorbeeld brasem voor paai ook gebruik kan maken van gebieden rond IJsselmeer en Markermeer. Bovendien is er natuurlijke variatie in de aanwas van jonge vis (jaarklassterkte). Effecten van jaarklassterkte op de omvang van een bestand kunnen wel groter worden als gevolg van intensieve visserij en de fluctuaties in de omvang van bestanden kunnen grilliger worden. Extreem slechte jaren (2014/2015) kunnen afwisselen met kortstondig betere jaren (2017/2018). 
De sterke afname van het brasembestand als bodemwoelende vis kan ook in zekere mate bijdragen aan helderder water (zie 4.4.3), zoals dat voor de Veluwerandmeren is gesuggereerd (Lammens et al. 2004).

Vanaf visseizoen 2014/2015 zijn maatregelen doorgevoerd om de visserij op snoekbaars, baars, blankvoorn en brasem in het IJsselmeer en Markermeer te beperken om te proberen verdere afname van de visstand te voorkomen. Sindsdien laten de vier bovengenoemde visbestanden geen achteruitgang meer zien, maar er zijn geen consistente signalen voor verbeteringen: baars en brasem laten geen verbetering van het bestand zien, het paaibestand van blankvoorn lijkt in 2017-2019 wel enigszins te herstellen en het paaibestand van snoekbaars nam consistent toe sinds 2015, met name door de zeer hoge nieuwe aanwas in 2017 (Tien et al. 2020). Echter, aangezien de aanwas in 2018 en 2019 weer laag was en de nieuwe aanwas van 2019 slecht is gegroeid, is de vraag of er sprake is van herstel of een tijdelijke opleving ten gevolge van toevallig sterke jaarklassen in 2017.

Daarnaast kan ook aalfuikenvisserij door bijvangst van jonge vis bijdragen aan verhoogde sterfte onder kleinere vis. De omvang van deze bijvangsten in recente jaren is niet bekend maar gaat waarschijnlijk om tenminste tientallen en mogelijk zelfs honderden tonnen per jaar (De Leeuw \& Van Donk 2020).

\subsection{Exoten}

De komst van invasieve vissoorten als zwartbekgrondel en pontische stroomgrondel die de afgelopen 5 jaar sterk zijn toegenomen kan betekenen dat deze concurreren om voedsel met andere bodemvissen zoals pos en riviergrondel. Deze laatste lijkt vrijwel geheel verdwenen te zijn uit het IJsselmeergebied, terwijl pos sterk afnam met de komst van deze invasieve grondels. Daarnaast kunnen deze nieuwe grondelsoorten zich ook territoriaal gedragen en mogelijk drager zijn van parasieten waartegen inheemse visfauna minder bestand is. Ook wordt wel genoemd dat grondels viseieren eten maar in welke omvang dat optreedt is geheel onduidelijk. Potentiele predatie op bijv. cypriniden-eieren is waarschijnlijk hoger dan die op baars-eieren (oneetbare eistrengen) en snoekbaarseieren (nest bewaking) (Kornis et al. 2012). De laatste 2 jaar lijkt het bestand exoten wat afgenomen, mede door optreden van witte stippenziekte onder zwartbekgrondels, maar het is nog onduidelijk of dat slechts van tijdelijke aard is.

Daarnaast grijpen exoten onder de bodemfauna ook in op het functioneren van het ecosysteem op verschillende manieren: quaggamossels (sinds 2009) versterken helderheid van het water (zie 4.4.3) en invasieve soorten macrofauna (diverse soorten gammariden bijvoorbeeld) kan als mogelijk voedsel voor vis fungeren, maar ook predatie op viseieren versterken (Platvoet et al. 2009). Deze mogelijke effecten zijn tot dusver niet of nauwelijks onderzocht.

\subsection{Milieuvreemde stoffen}

Andere oorzaken die genoemd worden en mogelijk bijdragen aan een minder goede visstand zijn milieuvreemde (toxische) stoffen zoals bestrijdingsmiddelen (herbiciden/pesticiden; neonicotinoiden), dioxines, hormonen, brandvertragers, e.d.. Dit zijn vaak toxische stoffen waarvan we pas veel later weten welke effecten ze hebben. Soms gaat het hierbij om meervoudige, cumulatieve effecten waar we geen weet van hebben voordat het zich voltrokken heeft.

De vraag is echter of dat ook voor het IJsselmeer een rol van betekenis kan spelen. Geen van de stoffen die als toxisch bekend staan en gemonitord worden in het IJsselmeer zijn toegenomen. Daarentegen worden significante afnames genoteerd van zware metalen, dioxine-achtige stoffen, chloorverbindingen, PFAS, herbiciden/pesticiden en zelfs de meer recente neonicotinoiden nemen af. Het IJsselmeer staat daarnaast bekend als relatief schoon ten opzichte van veel andere oppervlaktewateren in Nederland (pers. comm. Jaap Postma, Ecolife, en Michiel Kotterman, WMR). 
De concentraties in het oppervlaktewater kunnen daarentegen wat gemaskeerd worden wanneer milieuvreemde stoffen zich binden aan zwevend stof (sediment) zoals bijvoorbeeld in het Markermeer. Wanneer water helderder wordt door minder zwevend stof, kunnen bij lagere concentraties milieuvreemde stoffen mogelijk toch sterkere effecten optreden omdat deze stoffen dan "vrij" zijn en opgenomen kunnen worden door fytoplankton en zoöplankton en daarmee door vissen.

Nadere analyse naar samenhang met andere ecologische factoren wordt zelden gedaan en zouden hier meer licht op kunnen werpen. Daarnaast gaat het niet alleen om of stoffen toxisch zijn voor vissen zelf maar bijvoorbeeld ook voor andere organismen in het voedselweb en op die manier vissoorten indirect kunnen beïnvloeden (bijvoorbeeld voor voedselbeschikbaarheid).

\subsection{Uitspoeling vis via spuisluizen Afsluitdijk}

Een andere oorzaak die wordt genoemd is dat veel (jonge) vis uitspoelt naar de Waddenzee. Recent zijn echter de spuicondities eerder verbeterd dan verslechterd en ook lijkt de omvang van verliezen door spui in de ordegrootte van hooguit enkele procenten van het bestand niet zo groot als eerder wel is geraamd (De Leeuw \& van Donk 2020). Uitspoeling lijkt daarom niet sterk bij te dragen aan de recente veranderingen in de visstand. Naarmate vis zich meer concentreert in het noordelijk IJsselmeer zou echter een relatieve effect van uitspoeling iets toe kunnen nemen. 


\section{Conclusies, hypotheses en aanbevelingen}

\subsection{Veranderingen in visbestanden}

De belangrijkste observaties zijn dat de afgelopen decennia de visbestanden afnemen voor de meeste soorten in het IJsselmeer, zowel jonge als oudere leeftijdsgroepen. Deze afnames vinden echter niet voor alle soorten gelijktijdig plaats, maar in verschillende perioden. Brasem kende een sterke afname in de jaren '80 en '90 (De Leeuw et al. 2008), en vervolgens rond 2005, gevolgd door blankvoorn rond 2010, een tijdelijke opmars van pos rond 2000 gevolgd door een afname in 2015, en de opkomst van zwartbekgrondel en pontische stroomgrondel met relatief hoge aantallen tussen 2015 en 2017. Dit zijn allemaal vooral benthische soorten, dat wil zeggen dat ze vooral van bodemfauna leven. De leeftijdsverdelingen en de observatie dat kleine vis niet door lijkt te groeien is ook geen recent verschijnsel: al sinds 2000 zien we bestanden oudere vis sterk afnemen en verschuivingen naar relatief jonge visbestanden optreden. Dit geldt voor benthische soorten maar ook voor de piscivore baars en snoekbaars. De huidige situatie is dus niet acuut ontstaan maar eerder het resultaat van een geleidelijk of stapsgewijs proces. Om de oorzaken van de achteruitgang en huidige situatie te begrijpen is een perspectief over langere termijn daarom nuttig en moet rekening gehouden worden met dat meerdere factoren over die lange tijdsspanne een rol spelen. Ook zien we dat perioden met hogere biomassa's en lagere biomassa's elkaar af kunnen wisselen (bijvoorbeeld pos en baars in het IJsselmeer, blankvoorn en snoekbaars in het Markermeer). De vraag is in hoeverre dit natuurlijke schommelingen betreft of meer ecosysteemveranderingen. Met name voor de trends over de langere termijn is het echter zinvol hypotheses te formuleren die richting kunnen geven aan het beheer.

\subsection{Vergelijking Markermeer en IJsselmeer}

Bij een beschouwing van mogelijke oorzaken van de huidige toestand in het IJsselmeer biedt een vergelijking tussen het IJsselmeer en Markermeer inzichten. Een aantal factoren zijn namelijk gelijk voor beide meren en andere verschillend, zodat overeenkomsten en verschillen kunnen helpen bij het duiden van veranderingen. Zo zijn temperatuurontwikkelingen hetzelfde, is de afname van nutriënten behoorlijk vergelijkbaar, maar is het IJsselmeer onder meer directe invloed van de rivierafvoeren. Ook visserijdruk zou in principe vergelijkbaar moeten zijn: vissers zijn grotendeels vrij te kiezen waar ze vissen en zouden hun visinspanning kunnen verdelen over de meren naar rato van de visbestanden van de doelsoorten in beide meren. In recente jaren werd grote marktwaardige schubvis vooral in het Markermeer aangetroffen en heeft de visserij daarop zich hoofdzakelijk daar geconcentreerd. Dit geldt overigens niet voor de vaste locaties van grote aalfuiken en enkele visserijvrije zones. Het is op dit moment niet te zeggen in hoeverre vissers werkelijk hun inspanning verdelen over beide meren omdat ook andere afwegingen worden gemaakt bij het kiezen van vislocaties, zoals de nabijheid van de thuishaven en lokale kennis van visgronden.

Een belangrijk verschil tussen beide meren is de sedimenthuishouding en de directe (IJsselmeer) en meer indirecte verbinding (Markermeer) met de rivieren. Zoals in 5.1 is beschreven zijn nutriëntenbeschikbaarheid, algensamenstelling en daarmee een belangrijk deel van de voedselketens direct gekoppeld aan slib. Dat geldt vermoedelijk in nog veel sterkere mate voor bodemprocessen en het benthische deel van het voedselweb (P. Verdonschot, pers. comm.; Brinkmann et al. 2019). Dat betekent dat we rekening moeten houden met dat de voedselbasis aanzienlijk verschilt. De visbiomassa was tot voor kort bijna altijd groter in het IJsselmeer dan in het Markermeer, hoewel in recente jaren de visdichtheid bijna van dezelfde ordegrootte is. Wat vooral opvalt is dat in het IJsselmeer grotere vis ontbreekt, in het bijzonder grotere snoekbaars en blankvoorn, terwijl die wel in het Markermeer voorkomen. De biomassa jonge vis is daarentegen groter in het IJsselmeer dan in het Markermeer. 
Recente ontwikkelingen in infrastructuur in het Markermeer met aanleg van eilanden en vooroevers voor natuurontwikkeling, inclusief het ontstaan van nieuwe zandwinputten, behoren ook tot belangrijke verschillen. Het IJsselmeer is van nature dieper dan het Markermeer en vooral de geulen in het noorden afgewisseld met ondiepere delen zorgen vermoedelijk voor diversiteit en productieve habitats; bovendien zijn diepere geulen veiliger en mogelijk koeler en zuurstofrijker in warme perioden en daarmee aantrekkelijker voor vis.

Het Markermeer is doorgaans aanzienlijk troebeler dan het IJsselmeer. De helderheid varieert afhankelijk van de wind en van het seizoen: de kans op helder water is groter in het voorjaar en de voorzomer, en troebel water is nog altijd de norm in de wintermaanden. In het zuidelijk IJsselmeer daarentegen zijn verschuivingen richting (vaker) helder water het sterkst maar ook daar is de variatie in helderheid groot (Figuur 6).

\subsection{Matching met waarnemingen}

Om een indruk te krijgen van welke mogelijke verklaringen meer of minder de waarnemingen aan veranderingen in de visstand ondersteunen is op basis van expert judgement een kwalitatieve inschatting gemaakt (Tabel 1 ).

Zoals uit tabel 1 af te lezen valt, lijken veel waarnemingen samen te kunnen hangen met een verandering van de voedselsituatie, mede als gevolg van afname in fosfaat en stikstof. Dit zijn processen die al langere tijd spelen. Effecten van nutriënten hangen echter ook samen met slibhuishouding, rivierafvoer en temperatuur, en dus in samenspel met klimaatveranderingen, waardoor deze moeilijk te scheiden zijn.

Naast de voedselbasis lijken ook veel waarnemingen samen te hangen met de helderheid van het water. Deze op zich heeft weer te maken met het voedselweb (algen, mossels) en slibhuishouding.

Tabel 1. Overzicht matching waarnemingen en mogelijke verklaring.

\begin{tabular}{|c|c|c|c|c|c|c|}
\hline waarneming & $\begin{array}{l}\text { nutriënten } \\
\text { / voedsel }\end{array}$ & klimaat & helderheid & visserij & exoten & $\begin{array}{l}\text { toxische uitspoeling } \\
\text { stoffen }\end{array}$ \\
\hline Afname spiering & + & + & & & & \\
\hline Afname pos & + & & & & + & \\
\hline Afname brasem & + & & & + & + & \\
\hline Blankvoorn haven & + & & + & & & \\
\hline Houting & & & + & & & \\
\hline $\begin{array}{l}\text { Minder oudere vis in } \\
\text { IJsselmeer tov MM }\end{array}$ & & & + & & & \\
\hline $\begin{array}{l}\text { Meer vis noordelijk } \\
\text { IJsselmeer tov zuidelijk }\end{array}$ & + & & + & & & \\
\hline Snoekbaars mager IJM & + & & + & & & \\
\hline $\begin{array}{l}\text { Veel snoekbaars } \\
\text { Markermeer }\end{array}$ & & & + & & & \\
\hline $\begin{array}{l}\text { Grotere blankvoorn in } \\
\text { Markermeer }\end{array}$ & + & & & & & \\
\hline Piek vis laat in seizoen & + & & & & & \\
\hline
\end{tabular}

Aal mager

+ mogelijke oorzaak in lijn met waarneming 


\subsection{Hypotheses}

Er lijken dus meerdere factoren in samenspel rond de voedselsituatie en helderheid door te werken op de huidige visstand. Van Riel et al. (2019) analyseerden op basis van uitgebreide literatuurstudie en data analyse de ecologische veranderingen in specifiek het Markermeer. Belangrijke processen daarbij zijn (1) de rol van zwevend stof, (2) afname nutriënten, (3) effect zwavel op denitrificatie, (4) toxische stoffen, (5) verandering fytoplanktonsamenstelling, (6) verdwijnen sleutelsoorten voedselweb (driehoeksmossel, spiering), en (7) gebrek aan natuurlijke habitats (land-waterovergangen). Deze studie liet zien dat de ecologie van het Markermeer sterk wordt bepaald door perioden met wind gedreven resuspensie van sediment / zwevend stof en afnames in nutriënten. Ook deze studie benadrukt dus het samenspel tussen nutriënten, klimaat (wind) en helderheid. De rol van sediment en zwevend stof (c.q. troebelheid) is in het IJsselmeer echter aanzienlijk geringer, waardoor het IJsselmeer zich anders gedraagt en de reacties op klimaatveranderingen en nutriëntenreducties niet parallel lopen met die in het Markermeer.

De achterliggende mechanismen van de interacties tussen nutriënten, bodemprocessen, slib en daarmee de voedselbasis zijn complex en onvoldoende begrepen. Toch zit er wel een logische samenhang tussen een aantal genoemde mechanismen en verklaringen en de waarnemingen aan de veranderingen in de visstand. Deze samenhang is schematisch weergegeven in figuur 7, waarbij een centrale rol is weggelegd voor (1) de toename van helderheid van het water (blauw) en (2) veranderingen in het voedselweb (groen). De overige genoemde oorzaken kunnen deze effecten meer of minder versterken.

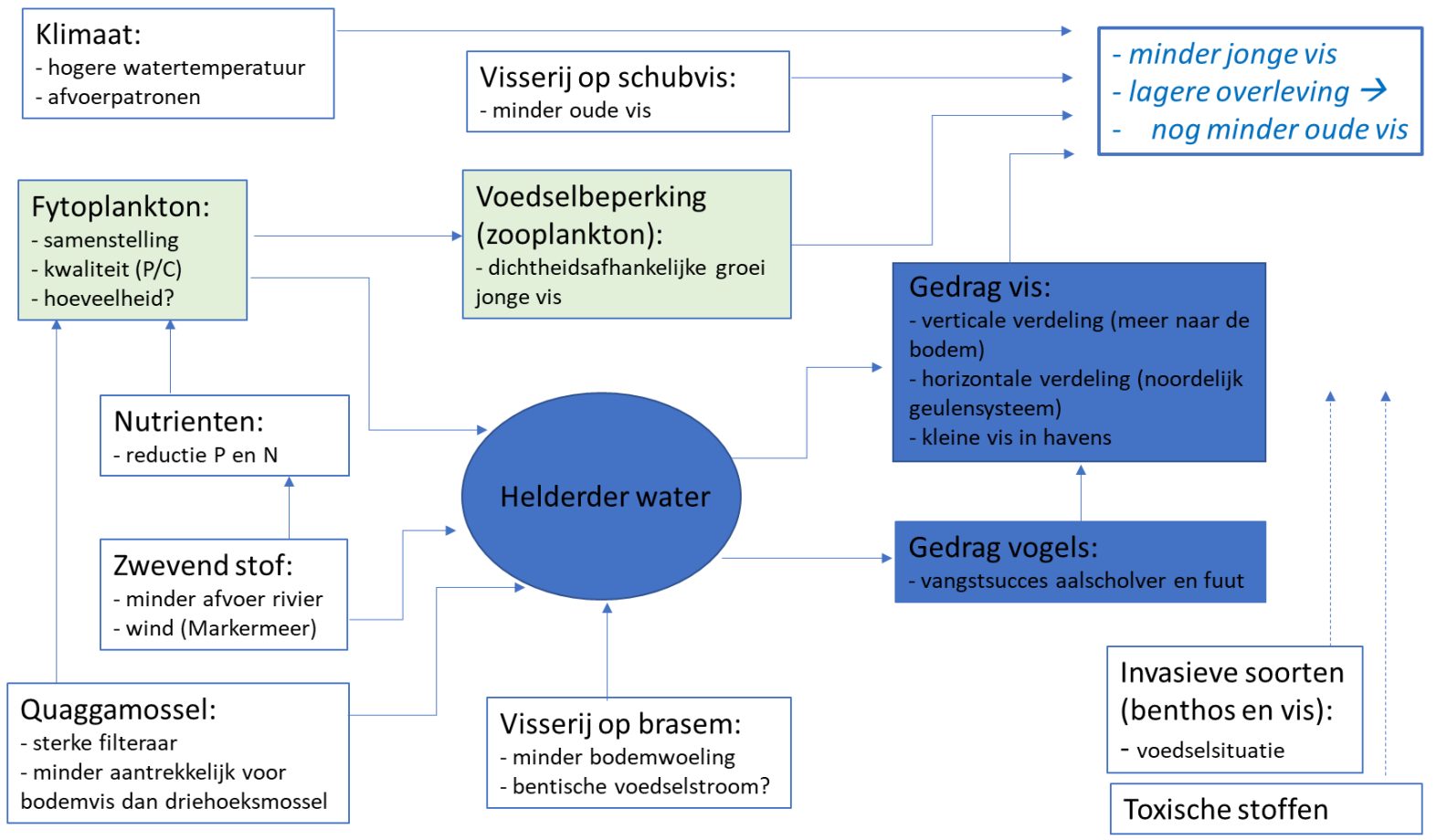

Figur 7. Synthese van hypotheses die mogelijk een verklaring kunnen bieden voor de afname van de biomassa vis in het IJsselmeer en de asymmetrische leeftijdsopbouw (zeer weinig grotere vis). Helder water en het gedrag van vissen en vogels (donkerblauw) en voedselbeperkingen in de planktonketen (lichtblauw) zijn aangegeven als de centrale mechanismen.

We kunnen op basis hiervan twee hypotheses formuleren voor de observatie dat er de laatste jaren weinig grote vis wordt waargenomen in het IJsselmeer:

(1) Voedselgebrek. Veranderingen in het voedselweb zorgen voor voedselbeperkingen in cruciale levensfasen van een aantal dominante schubvissoorten in het IJsselmeer, waardoor het doorgroeien naar oudere jaarklassen sterk is beperkt.

(2) Helder water verhoogt predatierisico. De toegenomen helderheid van het IJsselmeer versterkt het ontstaan van een 'landscape of fear' voor kleinere vis die een potentiële prooi vormt voor visetende vogels. Daardoor trekt jonge vis zicht terug naar een beperkt aantal wat veiliger gebieden. 
De waarnemingen aan de veranderingen in de visstand kunnen niet allemaal door hetzij de ene, hetzij de andere hypothese worden verklaard. De twee hypotheses geven echter een verschillend perspectief op de veranderingen, mogelijke oorzaken en denkbare maatregelen. Hieronder worden beide hypotheses daarom nader uitgewerkt.

\subsubsection{Hypothese 1: Voedselgebrek - gebrekkige nutriëntenstromen door onnatuurlijke oeverzones}

Veel van de recente waarnemingen duiden op dat voedselgebrek voor zowel planktivore vis als voor benthivore vis door een gebrek aan nutriënten sterk bijdragen aan de vermindering van de visstand in het IJsselmeer. N.B. Het feit dat eerst oudere vis lijkt te verdwijnen kan te maken hebben met overbevissing en met voedselarmere bodems en minder benthos, maar kan ook direct een gevolg zijn van dat de overleving van de jongere vis verminderd is door afname van voedselbeschikbaarheid (zoöplankton).

De afname van nutriëntenstromen is een proces dat zich op een lange tijd-ruimteschaal afspeelt. Een belangrijke aanname in deze hypothese is dat de inpolderingen het IJsselmeer hebben afgesneden van productieve oevers en achterland, waar ondieptes en vegetatierijke zones zorgden voor natuurlijke nutriëntentoevoer. Omdat nutriënten lang circuleren in het ecosysteem kunnen effecten uitgesmeerd worden over decennia. Deze effecten zijn in eerste instantie gemaskeerd door (hyper)eutrofiëring door externe bronnen. Nadat de antropogene fosfaat- en stikstofbelasting de afgelopen decennia sterk is verminderd wordt het gebrek aan natuurlijke nutriëntenbronnen steeds meer zichtbaar. Daaroverheen komen perioden voor waarin meer of minder nalevering van nutriënten, bioturbatie door vis (brasem) en benthos (wormachtigen), mogelijke interacties met slibhuishouding en variaties in rivierafvoer (retentietijd water, aanvoer nutriënten en sediment) tijdelijke switches veroorzaken door de complexe voedselwebinteracties.

Vooral in benthische soorten zien we dan een verschuiving: het verdwijnen van brasem en (grote) blankvoorn, het komen en gaan van pos en de opkomst van grondels. Daarmee ontstaat ook een in perioden andere wisselwerking tussen het benthische systeem en het pelagische system (fytoplankton en zoöplankton) en daarmee in de directe voedselbasis van jonge vis. Het is speculeren waar we in die wisselwerkingsfase zitten op dit moment, maar het is niet ondenkbaar dat er binnenkort ook weer jaren komen dat het wat gunstiger uitpakt voor jonge vis en ze wel door kunnen groeien.

Zoals eerder genoemd spelen de wisselwerking tussen klimaatveranderingen en nutriëntenbeschikbaarheid ook een rol. Inspiratie uit waar het naar toe gaat kan zowel gehaald worden uit voedselarmere systemen als uit systemen die warmer zijn en meer productief.

\subsubsection{Hypothese 2: Helder water - nieuwe baseline maar gebrek aan veiligheid}

Het steeds frequenter voorkomen van perioden met helder water zorgt enerzijds voor een een verschuiving van troebelwatersoorten zoals spiering en snoekbaars naar helderwatersoorten zoals baars en houting. Dat betekent dat we geleidelijk aan richting een nieuwe baseline gaan van welke soorten we mogen verwachten in het IJsselmeer. Dit lijkt op de verschuiving in de Veluwerandmeren die in de jaren 1990 omsloegen van troebel naar helder water, waarbij snoekbaars en brasem sterk afnamen en baars en blankvoorn toenamen, en het visbestand sterk verjongde. Vooralsnog is echter in het IJsselmeer geen sprake van plantenrijk, ondiep, helder water op grote schaal en het is zeer de vraag of het systeem zich zover in die richting zal ontwikkelen aangezien grote delen van het IJsselmeer (te) diep zijn voor uitgebreide ontwikkeling van waterplantvelden.

Helder water heeft een sterk effect op het anti-predatorgedrag van vis: vis zoekt een veilig heenkomen in dieper water (geulen, zandwinputten), troebeler water (indien mogelijk), tussen waterplanten (in de zomer), of in havens. Let wel, het gaat hier om beperkte, vaak niet-natuurlijke mogelijkheden. In meren met veel natuurlijke structuren (stenen, rietmoerassen, waterplantvelden, dood hout, etc.) zijn de overlevingskansen van jonge vis aanzienlijk groter. Versterkt door toegenomen mogelijkheden voor broeden (aalscholvers) en overwinteren (aalscholvers en futen) is 
het aantal aanwezige vogels per jaar toegenomen in het IJsselmeer. Door toegenomen helderheid is het vangstsucces van deze vogels zeer waarschijnlijk ook toegenomen (figuur 6). Dat betekent dat het predatierisico voor kleine vis toegenomen moet zijn, wat het antipredatorgedrag van vis aanzienlijk versterkt kan hebben. Het gaat daarbij niet alleen om hoe groot de kans is dat jonge vis een prooi wordt (hogere sterfte) maar ook het indirecte effect dat vis zich terugtrekt naar de relatief wat veiliger gebieden. Dat betekent dat een steeds groter areaal van het IJsselmeer ongeschikt wordt voor jonge vis en die jonge vis op een aanzienlijk kleiner areaal moet zien te overleven. De beperkte, relatief veilige arealen waar vis zich dan terugtrekt in dit zogenaamde 'landscape of fear' (Zanette \& Clinchy, 2019) kan bovendien extra vogels en roofvissen aantrekken waardoor de sterfte verder toeneemt.

Beide hypothesen versterken elkaar: vermindering van nutriënten kan zorgen voor een andere algensamenstelling die enerzijds via het zoöplankton de voedselbasis kan veranderen (zie hypothese 1), maar anderzijds ook bij kan dragen aan een grotere helderheid (hypothese 2). Ook quaggamossels versterken de helderheid (zuidelijk IJsselmeer) maar een sterk filterende werking van quaggamossels kan ook de algendichtheid en daarmee de voedselbasis (zoöplankton) voor jonge vis verlagen.

Daar waar jonge vis zich concentreert in wat meer veilige gebieden zijn ze afhankelijk van meer lokale voedselbronnen die dan eerder uitgeput raken (versterkend effect hypothese 1 ) en kan leiden tot extra sterfte. Ook is de voedselkeuze van planktivore vis en dus de benutbaarheid van zooplankton afhankelijk van de helderheid van het water (Horppila et al. 2019).

Het is aannemelijk dat juist zo'n combinatie van effecten leidt tot een gevoelig systeem, waarbij elke ongunstige verandering direct doorwerkt op de overleving van jonge vis. In zo'n situatie kunnen andere effecten zoals klimaat, visserij en exoten een versterkte rol spelen.

\subsection{Aanbevelingen voor maatregelen en onderzoek}

Als het gaat om maatregelen is de eerste vraag welk beleidsdoel maatregelen moeten dienen. Uit bovenstaande analyse en bespreking van hypotheses lijkt het terugdringen van nutriëntenoverschot van de jaren 1970 en 1980 ten behoeve van een verbetering van de waterkwaliteit een belangrijke oorzaak van een verminderde productie in het IJsselmeer met als gevolg een andere, kleinere visstand. De vraag is dan in hoeverre de huidige situatie (nog) afwijkt van een gewenste situatie die past bij de potenties van het IJsselmeer en de ambities van de beheerder. In onderstaande gaan we ervan uit dat de beleidsmatige wens is om zoveel mogelijk natuurlijke randvoorwaarden te scheppen voor een hogere visstand die bestaat uit meer grotere en oudere vis. Dit laatste sluit aan bij de wens van het Ministerie van LNV en vertegenwoordigers van het Bestuurlijk Overleg dat verantwoordelijk is voor het visstand- en visserijbeheer. De doelstelling van 'meer grote vis' komt voort uit de geformuleerde eisen vanuit de Kaderrichtlijn Water.

De waarnemingen en mogelijke verklaringen die in voorgaande hoofdstukken zijn besproken wijzen er ook op dat de belangrijkste maatregelen die een meer gevarieerde leeftijdsstructuur van de visstand zouden moeten bewerkstelligen gericht moeten zijn op:

- Verhogen van (natuurlijke) productie en beschikbaarheid van nutriënten die bijdragen aan hogere voedselproductie met name zoöplankton en bodemfauna.

- $\quad$ Verhogen van veiligheid (verlaging predatiedruk) voor een hogere overleving van jonge vis.

In veel natuurlijke meren met een florerende visstand zoals Peipsi, Vörtsjärv (divers in soortensamenstelling, groottestructuur en relatief hoge biomassa) worden beide gewaarborgd door natuurlijke, vegetatierijke land-waterovergangen. Ook in de Donaudelta vinden we meren met een zeer grote dichtheid en diversiteit aan visgemeenschappen en tegelijk veel visetende vogels als aalscholvers en pelikanen en ruimte voor visserij. Ook daar spelen uitgebreide rietmoerassen van deels drijvende rietvegetaties een cruciale rol. Dit lijkt het belangrijkste verschil met het huidige IJsselmeer en bepaalt in belangrijke mate de denkrichting van mogelijke maatregelen (Lammens et al. 2008). Het gaat daarbij dus niet alleen om geleidelijke oeverzones (zand/slik met flauwe taluds), maar met name ook om de structuur door vegetatie zoals rietmoerassen of dode bomen in het water dat kunnen bieden. Waterplantenrijke oevers en oeverzones dragen bij aan organische productie en 
bieden veiligheid (structuren die het vangstsucces door roofvissen en visetende vogels belemmeren). Deze structuren zijn vaak op zich ook productief omdat er organismen tussen en op deze structuren kunnen groeien, waardoor ook op die manier extra voedsel voor vis beschikbaar kan komen.

Van Riel et al. (2019) concluderen ook, langs grotendeels dezelfde gedachtenlijn, dat weliswaar de waterkwaliteitsdoelstellingen voor wat betreft de nutriëntenhuishouding zijn gehaald, maar dat het ecologisch herstel (van het Markermeer) ver achterblijft. Vermoedelijk spelen het gebrek aan natuurlijke land-waterovergangen, harde oevers en een onnatuurlijk waterpeilbeheer hierin een belangrijke rol.

\subsubsection{Wat kan verder onderzocht worden?}

Om de potenties van het IJsselmeer beter te begrijpen en daarmee beleidsambities voor maatregelen beter te kunnen formuleren worden in onderstaande de belangrijkste kennislacunes ten aanzien van de hypotheses besproken.

De hypothese dat de voedselsituatie beperkend is kent vele kennishiaten die te maken hebben met de complexiteit van het voedselweb en de (natuurlijke) dynamiek van interacties die soms meerdere jaren kunnen domineren en dan weer sterk in betekenis af kunnen nemen. Belangrijke kennishiaten die ons begrip van het huidige functioneren van het ecosysteem IJsselmeer kunnen vergroten zijn:

- Dynamiek en beschikbaarheid van zoöplankton als voedselbasis voor jonge vis. Het gaat hierbij vooral om de beschikbaarheid van verschillende typen zoöplankton (grootte, voedselkwaliteit) gedurende het groeiseizoen.

- De rol van veranderingen in benthosgemeenschap voor voedselproductie. Wormachtigen en muggenlarven zijn van groot belang als voedselbron en in natuurlijke bodemprocessen. Er is een enorme verschuiving naar veel meer uitheemse soorten ongewervelden opgetreden maar de consequenties daarvan voor het voedselweb zijn vrijwel onbekend.

- De interactie tussen bentische vissoorten als brasem, blankvoorn, pos en invasieve grondelsoorten (zwartbekgrondel en pontische stroomgrondel) is van belang: in hoeverre kunnen deze soorten naast elkaar bestaan en hoe is de interactie met de (veranderde) bodemfauna.

- Nutriëntenfluxen die de productie van het voedselweb voeden: bodemprocessen als bioturbatie, toevoer vanuit rivieren, nutriëntencycli in (natuurlijke) oeverzones zijn onvoldoende bekend om te begrijpen welke potenties er zijn voor de voedselproductie in het IJsselmeer.

- In het verlengde van de interne voedselsituatie en potentiële visproductie in het IJsselmeer is van groot belang wat de betekenis is van omliggende gebieden zoals Friese boezem, Zwarte water, IJsselmonding, e.d. voor visproductie: in hoeverre vormen deze gebieden paai- en opgroeigebieden die de visstand in het IJsselmeer kunnen bevorderen.

- Het is onduidelijk wanneer een zodanig hoge sterfte optreedt dat doorgroei naar grotere leeftijdsklassen sterk wordt beperkt. Dit zou onderzocht kunnen worden door in meerdere seizoenen visstandbemonsteringen uit te voeren om beter zicht te krijgen op het belang van wintersterfte (bijvoorbeeld door voedselgebrek in de winter, terwijl bij gemiddeld hogere watertemperatuur de voedselbehoefte hoger zou kunnen zijn dan vroeger), of juist sterfte in de vroege of late zomer (verschillende voedselbehoeften en voedselbeschikbaarheid).

- Wanneer meer bekend is over variaties over het seizoen kan met (relatief eenvoudige) modellen de energiehuishouding worden gesimuleerd waarbij de balans tussen voedselbeschikbaarheid en energieuitgaven (afhankelijk van de watertemperatuur en de grootte van de vis) kan worden onderzocht.

Ten aanzien van de hypothese dat helderheid van het water in toenemende mate zorgt voor een landscape of fear ontbreken belangrijke stukken in de puzzel:

- Wat veroorzaakt de helderheid en vooral de seizoensdynamiek daarin? Wat is de rol van algen, quaggamosselen, zoöplankton, brasems, sediment en wind, rivierafvoer, eventueel waterplanten, e.d. en wat zijn de verwachtingen voor de toekomstige ontwikkelingen? Met behulp van satellietbeelden en maandelijkse tellingen vanuit vliegtuigen kan een eerste stap worden gezet in het beschrijven van de dynamiek in helderheid en bijvoorbeeld de reactie van vogels daarop. 
- Hoe verandert het gedrag van vis in relatie tot perioden met helder water, voornamelijk ruimtelijke en verticale verspreiding van verschillende soorten en lengtegroepen? Welke rol speelt de grootte van vis in vluchtgedrag?

- Wat is de rol van visetende watervogels voor het gedrag van vis in verspreiding en habitatkeuze?

Hoewel het invullen van veel van bovenstaande kennishiaten vragen om meerjarig onderzoek kunnen er ook op korte termijn en met grotendeels al beschikbaar onderzoeksmateriaal al belangrijke stappen worden gezet.

Een gedetailleerde literatuurstudie van wetenschappelijk onderzoek van andere grote meersystemen zou zeer zinvol zijn. Er zijn bijvoorbeeld veel goed gedocumenteerde studies van de Great Lakes in Noord-Amerika, waar bijvoorbeeld ook invasies van driehoeksmossel, Quaggamossel en zwartbekgrondel hebben plaatsgevonden met als gevolg aanzienlijke verschuivingen in het voedselweb, de productie en de visgemeenschappen. De ontwikkelingen van meersystemen in Nederland zoals Volkerak-Zoommeer en Veluwemeer kunnen ook goede aanknopingspunten bieden. Daarnaast zijn binnen Europa bekende meren als Peipsi en Vörtsjärv in beeld, maar bieden vergelijkbare meren in Zweden en Duitsland ook aanknopingspunten. Daarbij zou specifiek gekeken kunnen worden naar factoren die voedselbeschikbaarheid, helderheid, en overleving (beperkte predatiedruk) voor jonge vis kunnen bepalen, hetzij op natuurlijke wijze hetzij door beheermaatregelen.

Op basis daarvan zou ook verder inzicht kunnen worden verkregen over wat de omvang van onderwatervegetatie en oevervegetatie zou moeten zijn om een significante rol te spelen voor visproductie en overleving en vervolgens ook nader onderzocht kunnen worden welke potenties het IJsselmeer daarbij heeft.

Op dit moment worden veel studies uitgevoerd naar het voedselweb en de productiviteit van het Markermeer. Het verdient aanbeveling om vergelijkbare studies in het IJsselmeer uit te voeren omdat zowel de visstand (dit rapport) als broedsucces vogels (visdieven) en ambitieuze Natura2000doelstellingen voor onder meer zwarte stern (zie ook De Leeuw \& Van Donk 2020) aangeven dat de situatie in het IJsselmeer nog verre van gewenst is op basis van de beheerdoelstellingen. Een nadere analyse van het voedselweb en de productie van zowel de bodem als de waterkolom zijn daarbij van belang. Een handicap daarbij zal zijn dat het IJsselmeer ruimtelijk gevarieerd is maar dat tijdreeksen van belangrijke waterkwaliteitsparameters en biologische parameters sterk beperkt zijn tot één (Vrouwenzand) of enkele meetpalen die niet op in alle opzichten representatieve locaties van het IJsselmeer liggen.

Het belang van gebieden rond het IJsselmeer voor vispopulaties is nauwelijks bekend, met name voor brasem en blankvoorn. Momenteel loopt een onderzoek naar brasems die voorzien zijn van zenders die communiceren met ontvangers die geplaatst zijn langs de randen van het IJsselmeer bij mogelijk belangrijke locaties die het IJsselmeer verbinden met het achterland en aangrenzende wateren (randmeren, Zwarte meer, Ketelmeer). Dit onderzoek zou een eerste licht kunnen werpen op de vraag of vissen uit het IJsselmeer substantieel gebruik maken van omliggende gebieden. Een volgende vraag is dan wat die gebieden bijdragen aan de vis- en/of nutriëntenproductie op het IJsselmeer.

De rol van vogels in de ontwikkelingen van de visstand en omgekeerd is nog maar zeer beperkt onderzocht. Uit literatuuronderzoek is wel bekend dat structuren het predatierisico voor vis kunnen beperken op kleine schaal, maar hoe dat op de schaal van het IJsselmeer zou kunnen functioneren, zowel de ruimtelijke verspreiding in een landscape of fear als het werkelijke predatierisico is vrijwel onbekend. De aanleg van eilanden die ook als broed- en rustgebied voor visetende watervogels kunnen fungeren kan consequenties hebben voor de lokale visstand. Het zou interessant zijn de ontwikkelingen op en rond de Kreupel in het noordelijk IJsselmeer nader te onderzoeken vanuit het perspectief van jonge vis en de rol van eilanden zowel in termen van voedselproductie als in termen van predatierisico en vanuit het perspectief van bijvoorbeeld aalscholvers (dieet, vangstsucces en broedsucces). Zo'n analyse kan van nut zijn bij bijvoorbeeld vragen of en zo ja waar en hoe eilanden eventueel in de toekomst aangelegd zouden moeten worden. 
In de jaren 1980 en 1990 zijn een aantal intensieve studies verricht naar de directe interacties tussen visetende vogels en vis. Inmiddels is de situatie, zowel de fysische factoren (nutriënten, temperatuur) als biologische (algen, samenstelling visstand en vogelstand en jaardynamiek daarin), aanzienlijk veranderd en zou een meer fundamentele basis voor de interacties tussen vogels en vis, zeker de mate van anti-predatorgedrag, van groot nut kunnen zijn. Daarvoor zijn gedegen veldstudies van belang die heel veel inzicht in het functioneren van het IJsselmeer kunnen bieden.

\subsubsection{Welke concrete maatregelen liggen voor de hand?}

Belangrijkste maatregelen met als doel meer grotere vis zouden gericht moeten zijn op:

- Verhogen van natuurlijke productie en beschikbaarheid nutriënten die bijdragen aan hogere voedselproductie.

- Verhogen van veiligheid voor een hogere overleving van jonge vis

Op dit moment zijn al vele maatregelen genomen of in gang gezet. Om de effectiviteit van deze maatregelen verder te verhogen kan gedacht worden aan:

(1) Natuurlijke oevers en rietmoerassen: grootschalige rietlanden en -oevers die direct bereikbaar zijn voor verschillende levensfasen van vissen (paai- opgroei- refugium) gedijen veruit het beste bij een natuurlijk fluctuaties in waterpeil. Dit is vermoedelijk de beste garantie voor gezonde, meer stabiele visgemeenschappen.

(2) Het aanleggen van eilanden en vooroevers. Dit kan in principe de basis zijn voor meer productieve oeverzones. Het onderzoek op Marker Wadden en Trintelzand kunnen daarbij veel inzicht geven. Daarbij is het van groot belang dit onderzoek niet alleen in de huidige pionierfase uit te voeren maar ook in verder gevorderde stadia en de, zij het schaarse, al veel oudere natuurlijke stukken habitat daarin mee te nemen.

(3) Vismigratiemogelijkheden naar het achterland. Naarmate de opties voor grotere arealen natuurlijke rietmoerassen beperkt zijn, kunnen verbindingen met vergelijkbare milieus in het achterland van belang zijn. Eventueel kan ook gedacht worden of het achterland meer veiligheid biedt voor jongere levensstadia zowel in de zomer als in de winter. Wanneer de vrije passagemogelijkheden voor verschillende soorten en grootteklassen meer beperkt zijn zal de bijdrage van het achterland aan visstand in het IJsselmeer ook beperkt zijn

(4) Verdere verduurzaming van beroepsvisserij zal leiden tot meer grote vis: momenteel wordt door veel partijen gewerkt aan een transitie van de beroepsvisserij op het IJsselmeer/Markermeer waarbij duurzaamheid, zowel voor de visstand als voor rendabele exploitatie, en rekening houden met ecologische randvoorwaarden centraal staan. Het meer op elkaar afstemmen van lopende en komende inrichtingsmaatregelen en visserijbeheersmaatregelen die in de nabije toekomst verwacht mogen worden in het kader van de transitie kunnen ertoe leiden dat beide typen maatregelen effectiever worden en het draagvlak voor beide typen toeneemt. 


\section{$7 \quad$ Kwaliteitsborging}

Wageningen Marine Research beschikt over een ISO 9001:2015 gecertificeerd

kwaliteitsmanagementsysteem. Dit certificaat is geldig tot 15 december 2021. De organisatie is gecertificeerd sinds 27 februari 2001. De certificering is uitgevoerd door DNV GL.

Het chemisch laboratorium te IJmuiden beschikt over een EN-ISO/IEC 17025:2017 accreditatie voor testlaboratoria met nummer L097. Deze accreditatie is geldig tot 1 april 2021 en is voor het eerst verleend op 27 maart 1997; deze accreditatie is verleend door de Raad voor Accreditatie. Het chemisch laboratorium heeft hierdoor aangetoond in staat te zijn op technisch bekwame wijze valide resultaten te leveren en te werken volgens de ISO17025 norm. De scope (L097) met de geaccrediteerde analysemethoden is te vinden op de website van de Raad voor Accreditatie (www.rva.nl).

Op grond van deze accreditatie is het kwaliteitskenmerk $Q$ toegekend aan de resultaten van die componenten die op de scope staan vermeld, mits aan alle kwaliteitseisen is voldaan. Het kwaliteitskenmerk Q staat vermeld in de tabellen met de onderzoeksresultaten. Indien het kwaliteitskenmerk $Q$ niet staat vermeld is de reden hiervan vermeld.

De kwaliteit van de analysemethoden wordt op verschillende manieren gewaarborgd. De juistheid van de analysemethoden wordt regelmatig getoetst door deelname aan ringonderzoeken waaronder die georganiseerd door QUASIMEME. Indien geen ringonderzoek voorhanden is, wordt een tweede lijnscontrole uitgevoerd. Tevens wordt bij iedere meetserie een eerstelijnscontrole uitgevoerd. Naast de lijnscontroles wordende volgende algemene kwaliteitscontroles uitgevoerd:

- Blanco onderzoek.

- Terugvinding (recovery).

- Interne standaard voor borging opwerkmethode.

- Injectie standard.

- Gevoeligheid.

Bovenstaande controles staan beschreven in Wageningen Marine Research werkvoorschrift ISW 2.10.2.105.

Indien gewenst kunnen gegevens met betrekking tot de prestatiekenmerken van de analysemethoden bij het chemisch laboratorium worden opgevraagd.

Indien sprake is van onbeheerste kwaliteit worden passende maatregelen genomen. 


\section{Literatuur}

Beekman, J.H., \& Platteeuw, M. 1994. Het nonnetje Mergus albellus in het IJsselmeergebied. Rapport 37 LIO.

Brinkmann, B.W., Vonk, J.A., van Beusekom, S.A.M., Ibanez, M., de Lucas Pardo, M.A., Noordhuis, R., Geest, H.G. 2019. Benthic hotspots in the pelagic zone: Light and phosphate availability alter aggregates of microalgae and suspended particles in a shallow turbid lake. Limnology and Oceanography, 64(2), 585-596. https://doi.org/10.1002/Ino.11062

Buijse, A.D. \& R.P. Houthuijzen 1992. Piscivory, growth and size-selective mortality of age 0 pikeperch, Stizostedion Iucioperca (L.). Canadian Journal Fisheries and Aquatic Sciences 49

De Leeuw, J. J. 2007. Zomersterfte spiering in het IJsselmeer en Markermeer. Rapport C086/07. Wageningen(September), 1-19.

De Leeuw, J.J., Dekker, W. \& Buijse, A.D. 2008. Aiming at a moving target, a slow hand fails! 75 years of fisheries management in Lake IJsselmeer, the Netherlands. Journal of Sea Research 60:21-31

De Leeuw J.J. \& S.C. van Donk 2020. Voedselreservering voor visetende vogels in het IJsselmeer en Markermeer. Wageningen Marine Research rapport C030/20.

Horppila, J., Härkönen, L., Hellén, N., Estlander, S., Pekcan-Hekim, Z. \& Ojala, A. 2019. Rotifer communities under variable predation-turbulence combinations. Hydrobiologia 828, 339-351 (2019). https://doi.org/10.1007/s10750-018-3823-5

Jeppesen, E., Mehner, T., Winfield, I. J., Kangur, K., Sarvala, J., Gerdeaux, D., Rask, M., Malmquist, H.J., Holmgren, K., Volta, P., Romo, S., Eckmann, R., Sandström, A., Blanco, S., Kangur, A., Ragnarsson Stabo, H., Tarvainen, M., Ventelä, A.-M., Søndergaard, M., Lauridsen, T.L. \& Meerhoff, M. 2012. Impacts of climate warming on the long-term dynamics of key fish species in 24 European lakes. Hydrobiologia, 694(1), 1-39. doi: 10.1007/s10750-012-1182-1

Kornis M. S., N. Mercado-Silva, M. \& Vander Zanden, J. 2012. Twenty years of invasion: a review of round goby Neogobius melanostomus biology, spread and ecological implications. Journal of Fish Biology 80: 235-285.

Lammens, E.H.H.R. 1999. Het voedselweb van IJsselmeer en Markermeer. Veldgegevens, hypotheses, modellen en scenario's. RIZA rapport 99.008

Lammens, E. H. R. R., E. H. van Nes, M.-L. Meijer \& M. S. van den Berg, 2004. Effects of commercial fishery on the bream population and the expansion of Chara aspera in Lake Veluwe. Ecological Modelling 177: 233-244.

Lammens, E., F. van Luijn, Y. Wessels, H. Bouwhuis, R. Noordhuis, R. Portielje, D. van der Molen, 2008. Towards ecological goals for the heavily modified lakes in the IJsselmeer area, The Netherlands. Hydrobiologia 599: 239-247

Mous, P.J. 2000. Interactions between fisheries and birds in IJsselmeer, The Netherlands. Thesis, Wageningen University.

Mous, P.J., W. Dekker, J.J. de Leeuw, M.R. van Eerden \& W.L.T. van Densen, 2003. Interactions in the utilisation of small fish by piscivorous fish and birds, and the fishery in IJsselmeer. In: (I.G. Cowx, Ed) Interactions between Fish and Birds: implications for management. Fishing News Books, Blackwell Science, pp 84-118

Mous, P.J., Van Densen, W.L.T., \& Machiels, M.A. 2004. Vertical distribution patterns of zooplanktivorous fish in a shallow, eutrophic lake, mediated by water transparency. Ecology of Freshwater Fish, 13, 61-69.

Noordhuis, R. 2000. Watersysteemrapportage IJsselmeer en Markermeer. RIZA rapport 2000.050.

Noordhuis, R. 2010. Ecosysteem IJsselmeergebied: nog altijd in ontwikkeling. Trends en ontwikkelingen in water en natuur van het Natte Hart van Nederland. Rapport ijg0910td061, Rijkswaterstaat Watersdienst, Lelystad.

Noordhuis, R., Groot, S., Pires, M. D., \& Maarse, M. 2014. Wetenschappelijk eindadvies ANTIJsselmeergebied. Vijf jaar studie naar kansen voor het ecosysteem van het IJsselmeer, Markermeer en IJmeer met het oog op de Natura-2000 doelen. Deltares rapport 1207767-000ZWS-0005.

Noordhuis, R. 2019. Survey zwavelbacteriën Markermeer 2019. Memo Deltares (i.o.v. RWS), Utrecht. 
Noordhuis, R. (2019, concept) Markermeer Helder of Troebel. Interactie tussen slib en biota in het Markermeer. Deltares rapport, Utrecht.

Piersma, T., R. Lindeboom, M.R. van Eerden 1988. Foraging rhythm of Great Crested Grebes Podiceps cristatus adjusted to diel variations in the vertical distribution of their prey Osmerus eperlanus in a shallow eutrophic lake in the Netherlands. Oecologia 76: 481-486.

Piersma, T., Wiersma, P., \& van Eerden, M.R. 1998. Seasonal changes in the diet of great crested grebes Podiceps cristatus indicate the constraints on prey choice by solitary pursuit-diving fisheaters. In Patchwork, PhD thesis University of Groningen (p. 351).

Platvoet D., G. van der Velde \& J.A. Dick 2009. Flexible omnivory in Dikerogammarus villosus (Sowinsky, 1894) (Amphipoda). Crustaceana 82

Tien, N., Mosqueira Sanchez I., Brunel T., van der Hammen T., Molla Gazi K., van Donk S., Foekema E., de Bruijn P., de Leeuw J.J. 2020. Bestandsoverzicht van snoekbaars, baars, blankvoorn en brasem en de evaluatie van potentiële oogstregels voor snoekbaars en baars in het IJssel/Markermeer. Wageningen Marine Research rapport C041/20.

Van Eerden, M. R., \& Voslamber, B. (1995). Mass fishing by cormorants Phalacrocorax carbo sinensis at Lake IJsselmeer, the Netherlands: A recent and successful adaptation to a turbid environment. Ardea, 83(1), 199-212.

Van Eerden, M.R., S.H.M. van Rijn \& M. Roos 2005. Ecologie en Ruimtegebruik door vogels en mensen in de SBZ's IJmeer, Markermeer en IJsselmeer. RIZA rapport 2005.014.

Van Emmerik W.A.M. \& J. Quak 2020. Functies van land-waterovergangen voor vissen. Sportvisserij Nederland, Bilthoven.

Van Riel, M.C., J.A. Vonk, R. Noordhuis, \& P.F.M. Verdonschot (2019). Novel ecosystems in urbanized areas under multiple stressors: Using ecological history to detect and understand ecological processes of an engineered ecosystem (lake Markermeer). Notitie Zoetwaterecosystemen, Wageningen Environmental Research, Wageningen UR, Wageningen. 34 pp.

Vijverberg, J. \& Frank, H. Th. 1976. The chemical composition and energy contents of copepods and cladocerans in relation to their size. Freshwater Biology 6: $333-345$

Vrooman, J., P. de Bruijn, J. Kampen, M. van der Sluis \& P. de Vries 2020. Op weg naar een duurzame visserij op het IJsselmeer- Markermeer; gezamenlijke bestandopnamen als stap naar breed gedragen vangstadviezen. Aanvulling 2019 en Evaluatie. Wageningen Marine Research rapport c042/20.

Witteveen+Bos 2008. Bureaustudie invloed Aalscholvers IJsselmeer en Markermeer op visstand en beroepsvisserij. Rapport DDT135-1/winb/027.

Zanette, L. Y. and Clinchy, M. 2019. Ecology of fear. Current Biology 29, R301-R316. 


\section{Verantwoording}

Rapport C051/20a

Projectnummer: 4316100218

Dit rapport is met grote zorgvuldigheid tot stand gekomen. De wetenschappelijke kwaliteit is intern getoetst door een collega-onderzoeker en het verantwoordelijk lid van het managementteam van Wageningen Marine Research

Akkoord:

Tessa van der Hammen

Onderzoeker

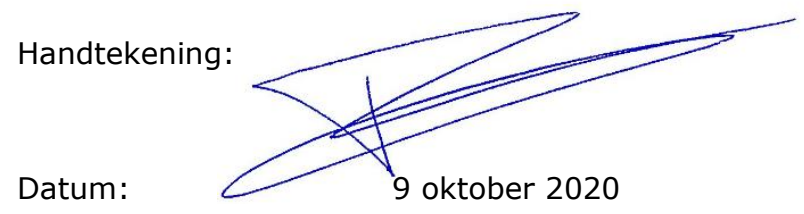

Akkoord: Tammo Bult director

Handtekening:



Datum:

9 oktober 2020 


\section{Bijlage 1 Zoöplankton}

Samenstelling en seizoensverloop van zoöplankton in IJsselmeer (Vrouwenzand) en Markermeer (Hoornsche Hop, Midden, Marker Wadden) in 2019 (data: Rijkswaterstaat, ongepubliceerd).
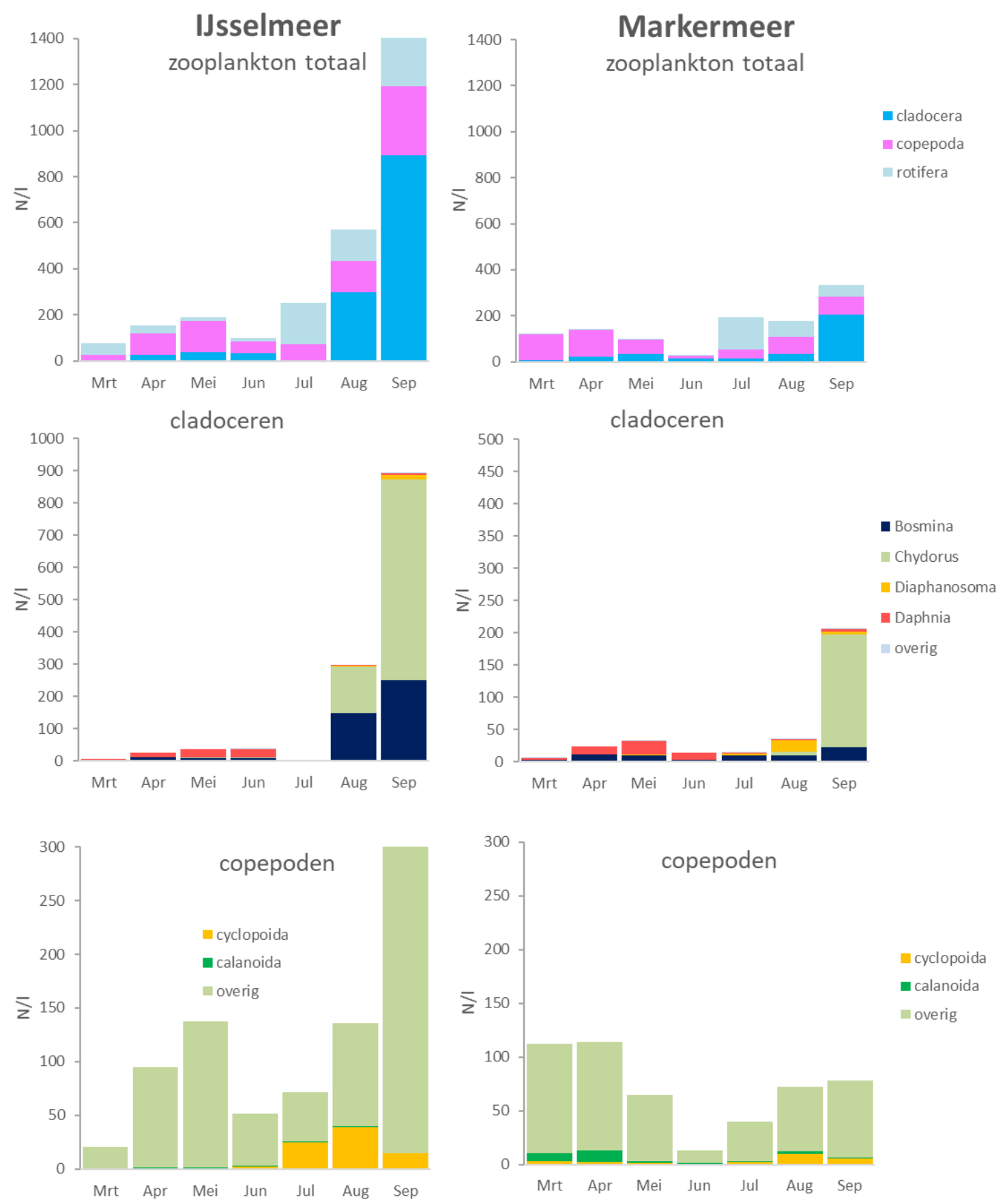
Samenstelling en seizoensverloop zoöplankton in IJsselmeer en Markermeer in 1996 (In: Noordhuis 2000)

Zooplankton totaal Isselmeer Zooplankton Lake Usselmeer

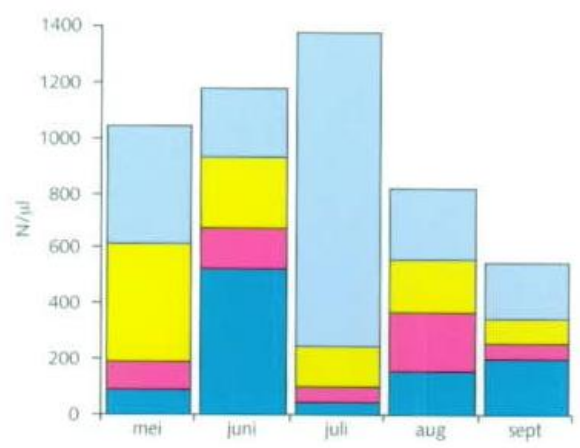

Cladoceren IJsselmeer Cladocerans Lake Usselmeer



Copepoden IJsselmeer Copepods Lake Usseimeer

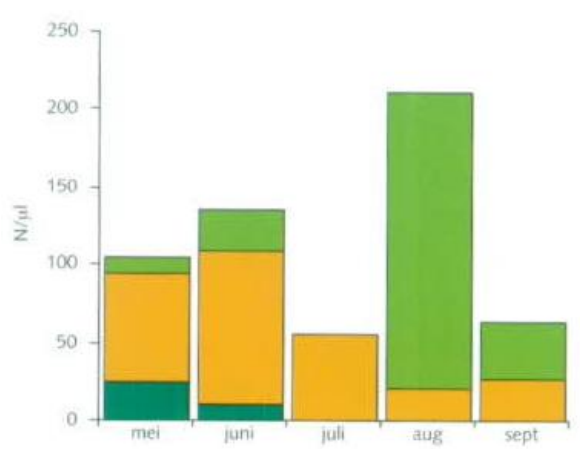

Zooplankton totaal Markermeer Zooplankton Lake Markermeet

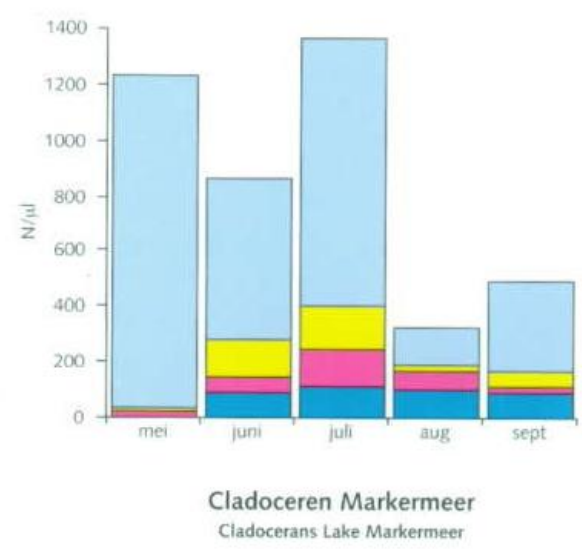

$\square$ Rotifera

$\square$ Nauplii

Copepoda

- Cladocera

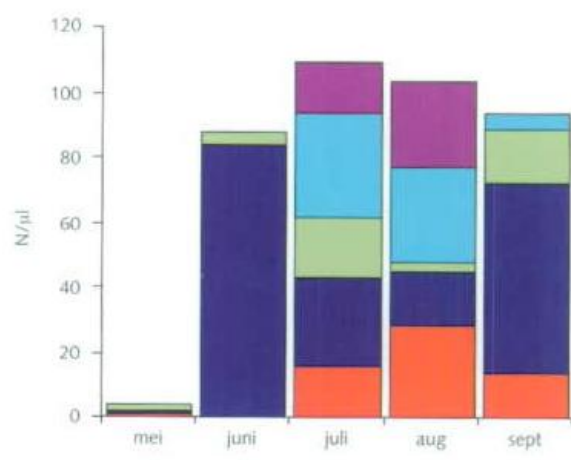

$\square$ overig, others

$\square$ Ceriodaphnia

$\square$ Chydorus

- Bosmina

Daphnia

Copepoden Markermeer Copepods Lake Markermeer



onbekend, unknown

$\square$ Cyclopoida

Calanoida 
Wageningen Marine Research

T: $+31(0) 317480900$

E: marine-research@wur.nl

www.wur.nl/marine-research

Bezoekers adres:

- Ankerpark 271781 AG Den Helder

- Korringaweg 7, 4401 NT Yerseke

- Haringkade 1, 1976 CP IJmuiden
Wageningen Marine Research levert met kennis, onafhankelijk wetenschappelijk onderzoek en advies een wezenlijke bijdrage aan een duurzamer, zorgvuldiger beheer, gebruik en bescherming van de natuurlijke rijkdommen in zee-, kust- en zoetwatergebieden.

Wageningen Marine Research is onderdeel van Wageningen University \& Research. Wageningen University \& Research is het samenwerkingsverband tussen Wageningen University en Stichting Wageningen Research en heeft als missie: 'To explore the potential of nature to improve the quality of life' 